\title{
Avaliação da integração do Programa de Erradicação do Trabalho Infantil ao Programa Bolsa Família
}

\author{
Maria das Graças Rua
}

\section{Introdução}

Este relatório apresenta o levantamento e a sistematização dos processos pelos quais foi implementada a integração do Programa de Erradicação do Trabalho Infantil (PETI) ao Programa Bolsa Família (PBF), com a identificação de algumas das principais lições aprendidas. Apresenta, também, uma avaliação dos efeitos, para o combate ao trabalho infantil, da mencionada integração. Espera-se que essa avaliação possa servir especialmente como apoio ao governo federal em seus esforços para o cumprimento dos dispositivos constitucionais que asseguram os direitos de crianças e adolescentes ao desenvolvimento saudável e integral.

Essa avaliação interessa especificamente aos seguintes usuários: o Fórum Nacional de Prevenção e Erradicação do Trabalho Infantil (FNPETI), a Organização Internacional do Trabalho (OIT), o Ministério do Desenvolvimento Social e Combate à Fome (MDS), os demais stakeholders - os gestores do Executivo, as Comissões Permanentes da Câmara dos Deputados (Comissão de 
Constituição, Justiça e Cidadania; de Direitos Humanos e Minorias; de Seguridade Social e Família; de Trabalho, Administração e Serviço Público; e de Educação e Cultura), os órgãos de controle externo e de controle social, bem como entidades da sociedade civil envolvidas com o combate ao trabalho infantil.

$O$ foco da avaliação incide fortemente sobre a implementação da integração do PETI ao PBF, ou seja, foram examinadas as estratégias, insumos, procedimentos e arranjos, inclusive institucionais, adotados para produzir resultado. As dimensões examinadas foram a clareza e o compartilhamento dos objetivos pelos gestores envolvidos no processo de integração e a adequação do desenho adotado para implementá-la. Trata-se também de uma avaliação de efetividade, compreendendo o exame dos efeitos dessa integração sobre a erradicação do trabalho infantil.

A partir do estabelecimento das dimensões acima, aplicaram-se os seguintes critérios de avaliação:

- Eficácia: em que medida a integração contribuiu para o cumprimento dos objetivos e metas de redução do trabalho infantil no Brasil?

- Eficiência: a integração contribuiu para a maximização dos resultados na aplicação dos recursos do PETI? O acesso às atividades socioeducativas e de convivência (Asec) foi ampliado e garantido para todas as crianças e adolescentes ex-trabalhadores atendidos pelo PETI e pelo PBF? Os parâmetros pedagógicos para a jornada ampliada foram definidos contemplando o atendimento às crianças abaixo de seis anos?

- Efetividade: quais os resultados obtidos versus os resultados esperados da integração dos programas? Houve resultados não-antecipados, positivos e negativos? De que natureza?

- Eqüidade: como foram abordados os aspectos relativos à justiça social na seleção dos beneficiários? A integração tem propiciado a focalização adequada?

- Transparência: o Cadastro Único (CadÚnico) ${ }^{1}$ assegura mais transparência a esses programas governamentais? Contribui para o aprimoramento da gestão dos programas?

- Participação social: a integração contribuiu para o fortalecimento dos canais de interlocução dos gestores e dos demais interessados?

- Sustentabilidade: que formas de mudança institucional foram constituídas para a redução e/ou erradicação do trabalho infantil? $\mathrm{O}$ que foi feito para que as partes envolvidas não reincidam no trabalho infantil?

Essa avaliação baseou-se em dois tipos de dados: em documentos oficiais dos dois programas, obtidos em meio impresso ou eletrônico junto ao Ministério do Desenvolvimento Social e Combate à Fome ( MDS), ao Ministério do Planejamento, Orçamento e Gestão (MP), ao Ministério do Trabalho e Emprego (MTE), ao Tribunal de Contas da União (TCU) e a outras instituições públicas envolvidas; e em percepções e avaliações dos principais gestores sobre os dois programas e a sua integração. Após o levantamento inicial dos documentos, procedeu-se à análise dos mesmos.

Em seguida, a fim de explorar as dimensões selecionadas para a avaliação, nos meses de fevereiro e março de 2007, foram realizadas entrevistas semi-estruturadas com os principais gestores envolvidos no MDS, no MP e no MTE, cujas identidades, em obediência à ética de pesquisa, serão preservadas ${ }^{2}$. 
É necessário registrar que este trabalho enfrentou uma série de limitações. Primeiramente, registra-se o reduzido prazo de realização, em período de festas de final de ano e férias, o que atrasou as atividades de coleta de dados. Além disso, o trabalho foi dificultado pelo contexto de mudança governamental, já que o momento foi marcado pelas expectativas de reforma ministerial, que impuseram obstáculos ao acesso a vários informantes. Finalmente, posto que a integração do PETI ao PBF por intermédio do Cadastro Único só alcançou magnitude significativa no segundo semestre de 2006, os resultados desse processo ainda estão se consolidando, sendo o momento atual ainda cedo para conclusões definitivas.

Este documento está dividido em cinco seções, além desta introdução. Na primeira, é descrito o Programa de Erradicação do Trabalho Infantil. Na segunda, apresentamse as principais características do Programa Bolsa Família. Na terceira, é descrita e discutida a integração dos dois programas nos termos estabelecidos pelo governo federal e atualmente vigentes. Na quarta, são aplicados os critérios de avaliação e apresentadas as principais constatações a partir da análise realizada. Por último, na quinta seção, são apresentadas as recomendações e um conjunto de indicadores para avaliação de resultados e de processos do PETI.

\section{Descrição dos objetos de avaliação: Programa de Erradicação do Trabalho Infantil}

Em 1980, registraram-se no Brasil cerca de 6,9 milhões de crianças e adolescentes em situação de trabalho. Em 1992, registraram-se 9,6 milhões com idade entre cinco e 17 anos. Em 1995, esse número decresceu para 9,5 milhões. As causas desse fenômeno são múltiplas: a pobreza e a miséria; as distorções do sistema econômico; as limitações do sistema educacional; e as restrições impostas pelos aspectos culturais.

Em 1998, a incidência do trabalho infantil no Brasil começou a alterar-se de modo significativo, totalizando cerca de 7,7 milhões de crianças e adolescentes; em 1999 esse número foi reduzido para 6,6 milhões.

\section{“Em 1980,}

registraram-se no Brasil cerca de 6,9 milhões de crianças e adolescentes em situação de trabalho. (...) As causas desse fenômeno são múltiplas: a pobreza e a miséria; as distorções do sistema econômico; as limitações do sistema educacional; $e$ as restrições impostas pelos aspectos culturais."

Em 2001, de acordo com a Pnad, cerca de 5,5 milhões de crianças e adolescentes com idade entre cinco e 17 anos encontravam-se em situação de trabalho precoce. Dentre eles, cerca de 300 mil estavam na faixa etária de 5 a 9 anos; 2,8 milhões entre 10 e 15 anos; e 2,4 milhões estavam entre os 16 e 17 anos de idade.

De acordo com a legislação brasileira, trabalho infantil é aquele exercido por 
qualquer pessoa com menos de 16 anos de idade. No entanto, é permitido o trabalho a partir dos 14 anos de idade, desde que na condição de aprendiz. Aos adolescentes de 16 a 18 anos está proibida a realização de trabalho em atividades insalubres, perigosas ou penosas; de trabalho que envolva cargas pesadas e/ou jornadas longas; e, ainda, de trabalho em locais ou serviços que lhes prejudiquem o bom desenvolvimento psíquico, moral e social.

O Programa de Erradicação do Trabalho Infantil iniciou-se em 1996, como experiência piloto implantada nas carvoarias do Estado do Mato Grosso do Sul, onde foram atendidas 1.500 crianças e adolescentes que trabalhavam nos fornos de carvão e na colheita da erva-mate, em 14 municípios. No ano de 1997, foi implantado nos canaviais de Pernambuco e na região sisaleira da Bahia, ampliando-se o atendimento também aos Estados do Amazonas e de Goiás. Em 1998, foi estendido para a região citrícola do Sergipe, para áreas de garimpo em Rondônia e de canaviais no litoral fluminense. A partir de 1999, o programa teve sua abrangência ampliada para diversas atividades nos demais estados do País, bem como se estendeu a novos municípios nos estados já atendidos.

Inicialmente, o PETI tinha por finalidade erradicar o trabalho infantil de crianças e adolescentes de 7 a 14 anos, em atividades consideradas perigosas, insalubres, penosas ou degradantes, nas zonas urbana e rural. Sua ação tinha como referência principal o núcleo familiar e, subsidiariamente, a escola e a comunidade. $O$ público-alvo era constituído, prioritariamente, por famílias com renda per capita de até $1 / 2$ salário mínimo, com filhos na faixa etária de sete a 14 anos em situação de trabalho nas atividades mencionadas $^{3}$.
Em 2001, o PETI concedia às famílias incluídas um benefício financeiro denominado Bolsa Criança Cidadã, no valor de $R \$ 25,00$ para a área rural e de $R \$ 40,00$ para a urbana, por criança que freqüentasse a jornada escolar ampliada.

No PPA 2000-2003 as ações orçamentárias estruturadas para a implementação do PETI eram prioritariamente as seguintes: concessão de Bolsa Criança Cidadã; atendimento a criança e ao adolescente em jornada escolar ampliada; geração de ocupações produtivas para as famílias do PETI, todas inicialmente a cargo da Secretaria de Estado de Assistência Social, do Ministério da Previdência e Assistência Social (Seas/MPAS); fiscalização para erradicação do trabalho infantil; e mapeamento dos focos de trabalho infantil por município, a cargo do $\mathrm{MTE}^{4}$.

De 2001 a 2005, o PETI passou por diversas modificações devido a mudanças de natureza institucional. Em 2001, encontrava-se sob a responsabilidade da Seas, que integrava o então Ministério da Previdência e Assistência Social. Em 2003, com a mudança de governo, a Seas foi transformada no Ministério da Assistência Social que, em janeiro de 2004, foi transformado no Ministério do Desenvolvimento Social e Combate à Fome (MDS). Atualmente, a Secretaria Nacional de Assistência Social (SNAS) é a responsável pela execução do programa, por meio do Departamento de Proteção Social Especial. Além disso, foram adotadas providências diversas no sentido do aperfeiçoamento dos mecanismos para sua implementação.

Em 2006, o PETI apresentava as seguintes características:

- o valor da bolsa para as famílias residentes em áreas rurais ou em municípios com menos de 250 mil habitantes era de $\mathrm{R} \$ 25,00$, e para as famílias residentes em 
áreas urbanas com mais de 250 mil habitantes era de $R \$ 40,00$ por criança retirada do trabalho. Não há limite do número de bolsas por família;

- além da bolsa, a SNAS repassava aos municípios o valor de $\mathrm{R} \$ 20,00$ por criança ou adolescente beneficiário das atividades socioeducativas e de convivência no horário extra-escolar (jornada ampliada). Essa ação visava ao desenvolvimento, em período extracurricular, de atividades de reforço escolar, alimentação, ações esportivas, artísticas e culturais;

- a faixa etária das crianças e adolescentes beneficiários, inicialmente de 7 a 14 anos, passou a ser de 7 a 15 anos $^{5}$, e o programa passou a atender também crianças e adolescentes vítimas de exploração sexual comercial;

- para receber o benefício, a família obrigatoriamente deveria retirar das atividades laborais todos os filhos menores de 16 anos, e da exploração sexual comercial caso houvesse - todos os filhos menores de 18 anos; assegurar que crianças e adolescentes beneficiários tivessem freqüência mínima de $75 \%$ das atividades escolares e das atividades socioeducativas e de convivência. As ações de controle do cumprimento das contrapartidas exigidas pelo programa deveriam ser executadas pelos municípios.

As famílias incluídas e selecionadas no Cadastro Único (CadÚnico) recebiam os benefícios por meio de cartão magnético da Caixa Econômica Federal (CAIXA), que lhes repassava diretamente os recursos do MDS. As famílias selecionadas, porém não incluídas no CadÚnico, recebiam os benefícios diretamente da prefeitura, por meio do repasse do Fundo Nacional de Assistência Social (FNAS) ao Fundo Municipal de Assistência Social (FMAS).

- para serem inseridos no PETI, os municípios e estados deveriam apresentar termo de adesão, ter suas comissões de erradicação do trabalho infantil formalmente criadas, instaladas e dotadas de um plano de ação.

- para serem atendidos pelo programa, inicialmente os estados deveriam apresentar um levantamento dos casos de trabalho infantil que ocorrem em seus municípios. Esse estudo diagnóstico era apresentado às Comissões Estaduais de Erradicação do Trabalho Infantil para validação e estabelecimento de critérios de prioridade para atendimento às situações identificadas. Com isso, priorizava-se o atendimento a municípios em pior situação econômica ou que apresentassem atividades mais prejudiciais, em termos comparativos, à saúde e à segurança da criança e do adolescente.

As demandas validadas pela comissão estadual eram submetidas à Comissão Intergestora Bipartite (Cib), para que fosse realizada a pactuação. Essas decisões eram informadas ao MDS, sendo remetida, nessa oportunidade, a relação nominal de crianças e adolescentes a serem atendidos e as respectivas atividades econômicas exercidas. O Ministério, então, aprovava e informava ao governo estadual as etapas a serem cumpridas pelos municípios para implantação do programa.

As principais etapas eram: inserção das famílias no Cadastro Único dos programas sociais do governo federal ${ }^{6}$; inserção ou reinserção das crianças e dos adolescentes na escola; seleção, capacitação e contratação de monitores para trabalhar na jornada ampliada; estruturação do espaço físico para a execução da jornada ampliada; encaminhamento do plano de ação, preenchido e assinado pelo gestor municipal; envio da declaração emitida pela Comissão Municipal de Erradicação do Trabalho Infantil, atestando o cumprimento de todas as etapas. 
No PPA 2004-2007, o PETI passou a compreender as seguintes ações: Bolsa Criança Cidadã; apoio aos fóruns de erradicação do trabalho infantil; atendimento à criança e ao adolescente em jornada ampliada, sob responsabilidade do MDS; fiscalização para erradicação do trabalho infantil; publicidade de utilidade pública; atualização do mapa de focos de trabalho infantil; e apoio técnico à Escola do Futuro Trabalhador, sob responsabilidade do MTE.

O controle social é realizado por intermédio das Comissões Municipal e Estadual de Erradicação do Trabalho Infantil, compostas por órgãos governamentais, representantes da sociedade civil e por membros dos Conselhos de Assistência Social, Conselhos Tutelares e Conselhos dos Direitos da Criança e do Adolescente. Entre os órgãos governamentais participantes destacam-se a Secretaria Nacional de Assistência Social e as Delegacias Regionais do Trabalho (DRTs).

\section{Descrição dos objetos de ava- liação: Programa Bolsa Família}

O Programa Bolsa Família (PBF) foi criado pela Lei no $10.836 / 2004$, que unificou os procedimentos de gestão e execu- ção das ações de transferência de renda do governo federal criadas e implantadas entre 2001 e 2003 e que passaram a ser denominadas "programas remanescentes" (Programas Cartão Alimentação, BolsaEscola, Bolsa-Alimentação e AuxílioGás $)^{7}$. Entre eles, não se inclui o PETI.

Os objetivos do PBF são: promover o acesso à rede de serviços públicos, em especial, de saúde, educação e assistência social; combater a fome e promover a segurança alimentar e nutricional; estimular a emancipação sustentada das famílias que vivem em situação de pobreza e extrema pobreza; combater a pobreza; e promover a intersetorialidade, a complementaridade e a sinergia das ações sociais do poder público.

As famílias elegíveis para o PBF compreendem dois grupos aos quais correspondem dois tipos de benefícios, descritos no Quadro 1.

No que se refere a metas, de acordo com informações da gerência do Bolsa Famillia, o Programa deveria atender cerca de 6,5 milhões de familias ao final de 2004, passando para 8,8 milhões ao final de 2005, para finalmente atender as estimadas 11,2 milhões de famílias em situação de pobreza em 2006. Em abril de 2004, o PBF atendia 3.766 .740 familias,

\section{Quadro 1: Tipologia de famílias beneficiárias e de benefícios do Programa Bolsa Família - valores para 2007}

\begin{tabular}{|ll|}
\hline Grupo 1 & Grupo 2 \\
\hline $\begin{array}{l}\text { Famílias com renda per capita mensal de até } \mathrm{R} \$ 60,00, \\
\text { independentemente da composição e do número de } \\
\text { membros da família. }\end{array}$ & $\begin{array}{l}\text { Famílias com renda mensal per } \\
\text { capita de } \mathrm{R} \$ 60,01 \text { até } \mathrm{R} \$ 120,00\end{array}$ \\
\hline Benefício 1 & Benefício 2 \\
\hline $\begin{array}{l}\text { Benefício fixo de } \mathrm{R} \$ 50,00 \text {, acrescido do benefício variável de } \\
\mathrm{R} \$ 15,00 \text { por beneficiário, até o limite de } \mathrm{R} \$ 45,00, \text { podendo } \\
\text { a soma chegar ao total de } \mathrm{R} \$ 95,00 \text { por mês. }\end{array}$ & $\begin{array}{l}\text { Benefício variável por filho } \\
\text { menor de } 15 \text { anos, podendo } \\
\text { chegar a } \mathrm{R} \$ 45,00 \text { por mês. }\end{array}$ \\
\hline
\end{tabular}


das 11.208.273 famílias estimadas, ou seja, cobria $33,6 \%$ da sua meta final.

A Lei $\mathrm{n}^{\circ}$ 10.836, de 9 de janeiro de 2004, foi regulamentada pelo Decreto $\mathrm{n}^{\circ}$ 5.209, de 17 de setembro de 2004. Este decreto instituiu o arranjo institucional para a implementação do PBF, que assume o seguinte desenho.

A instância máxima de gestão do PBF é o Conselho Gestor do Programa Bolsa Família (CGPBF), órgão colegiado de caráter deliberativo, vinculado ao MDS, previsto pelo Art. 4ㅇ da Lei no 10.836 , de 2004, e pela Lei $\mathrm{n}^{\circ} 10.869$, de 13 de maio de 2004.

O CGPBF tem por finalidade formular e integrar políticas públicas, definir diretrizes, normas e procedimentos sobre o desenvolvimento e implementação do Programa Bolsa Família, bem como apoiar iniciativas para instituição de políticas públicas sociais visando promover a emancipação das famílias beneficiadas pelo programa nas esferas federal, estadual, distrital e municipal. O Comitê Executivo do CGPBF terá como finalidade implementar e acompanhar as decisões do Conselho.

A execução e gestão do Programa Bolsa Família dar-se-á de forma descentralizada, por meio da conjugação de esforços entre os entes federados, observada a intersetorialidade, a participação comunitária e o controle social. Os entes federados poderão aderir ao programa por meio de termo específico, observados os critérios e as condições estabelecidas pelo MDS.

Portanto, na esfera federal cabe ao MDS deliberar sobre o desenho e a implementação do programa; coordenar sua operacionalização, principalmente no que diz respeito às funções de cadastro, pagamento de benefícios, monitoramento e avaliação; e atuar na coordenação política e na articulação com os entes federados.
A estrutura regimental do MDS, aprovada pelo Decreto 5.074, de maio de 2004, definiu que compete à Secretaria Nacional de Renda de Cidadania (Senarc) coordenar, implementar, acompanhar e controlar os programas e projetos relativos à Política Nacional de Renda de Cidadania, em conjunto com os estados, o Distrito Federal e os municípios. Em outras palavras, o PBF é gerido pela Senarc, a qual

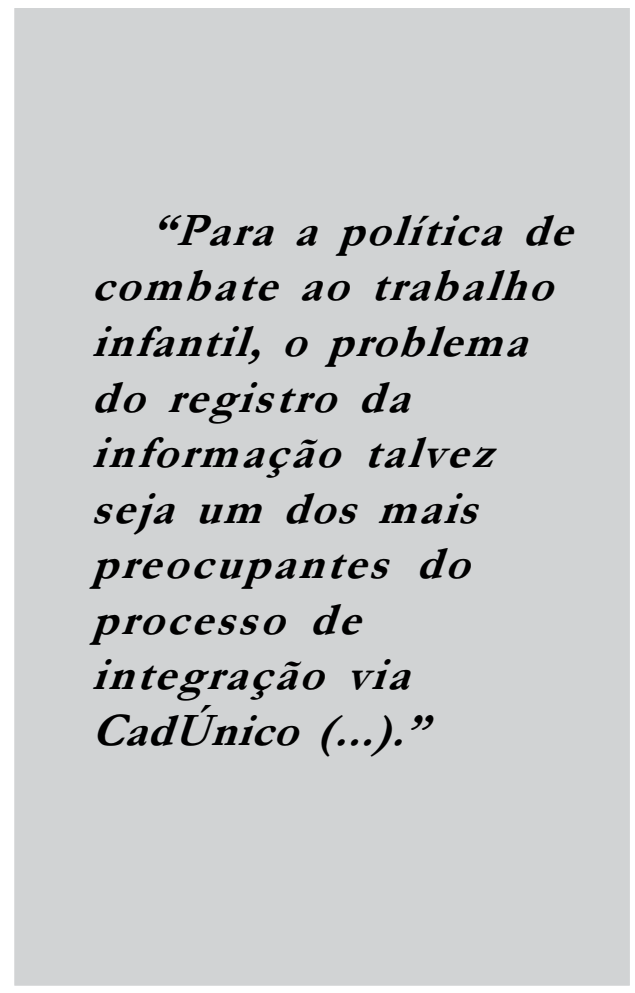

gerencia o CadÚnico, que é a porta de entrada do programa.

Ainda na esfera federal, cabe ao Ministério da Saúde e ao Ministério da Educação normatizar as condicionalidades que lhes dizem respeito e verificar seu cumprimento por parte das famílias; monitorar e buscar suprir as deficiências na oferta de serviços sociais pelos entes federados; acompanhar a evolução dos 
indicadores sociais setoriais; articular-se com os respectivos conselhos setoriais para a implementação do programa; e participar das decisões que dizem respeito às funções centralizadas de gestão do programa (cadastro, pagamento de benefícios, monitoramento e avaliação).

Cabe aos governos estaduais, principalmente, apoiar a implementação do PBF no estado; promover a articulação das ações para assegurar o caráter intersetorial do programa; viabilizar a oferta de serviços e de ações complementares; apoiar os municípios no processo de cadastramento; apoiar os conselhos estaduais e municipais; e colaborar com o Poder Judiciário na redução do sub-registro civil e na emissão de documentação para as famílias.

De acordo com o modelo de gestão descentralizada, os governos municipais são os principais gestores do PBF junto às famílias. As suas principais atribuições são articular os diversos órgãos e entidades locais afetos ao programa; assegurar a oferta de serviços essenciais de saúde, educação, acompanhamento alimentar e nutricional para viabilizar o cumprimento das condicionalidades; viabilizar a oferta de ações complementares ao programa; coordenar o processo de cadastramento, seleção, renovação, suspensão e desligamento das famílias beneficiárias, mediante a operação do CadÚnico; atender diretamente os beneficiários; capacitar os profissionais envolvidos (em conjunto com o nível federal); avaliar o desempenho e o impacto do programa no município; apoiar os conselhos municipais; colaborar com o Poder Judiciário na redução do subregistro civil e na emissão de documentação para as famílias beneficiárias; e informar periodicamente ao MDS e aos ministérios setoriais os dados sobre o cumprimento das condicionalidades.
A CAIXA atua como agente operador do Cadastro Único e agente pagador dos benefícios do PBF, que são recebidos pelos beneficiários por meio de cartões magnéticos.

A exemplo do que ocorre com a maioria das ações federais descentralizadas, o PBF prevê instância de controle social local. De acordo com a Portaria GM/ MDS no 246, de 20 de maio de 2005, que institui os instrumentos necessários e define o procedimento de adesão dos entes locais ao PBF, a primeira condição a ser cumprida para a adesão é a existência formal e o pleno funcionamento de um comitê ou conselho local de controle social do Programa Bolsa Família.

O artigo 29 do Decreto 5.209 já havia estabelecido que o controle e a participação social do PBF devem ser realizados, em âmbito local, por conselho formalmente constituído pelo município ou pelo Distrito Federal, respeitada a paridade entre governo e sociedade; composto por integrantes das áreas da assistência social, da saúde, da educação, da segurança alimentar e da criança e do adolescente, quando existentes, sem prejuízo de outras áreas que o município ou o Distrito Federal julgue conveniente. No nível estadual, o controle social do PBF pode ser exercido por conselho, instituído formalmente, nesses mesmos moldes. Por decisão do poder público municipal ou do Distrito Federal, o controle social do PBF pode ser realizado por conselho ou instância anteriormente existente, garantidas a paridade e a intersetorialidade. A norma admite, também, que os municípios podem associar-se para exercer o controle social do PBF, desde que se estabeleça formalmente, por meio de termo de cooperação intermunicipal, a distribuição de todas as competências e atribuições necessárias ao perfeito acompanhamento 
dos Programas Bolsa Família e remanescentes sob sua jurisdição.

Atualmente o controle social acompanha e avalia a execução do PBF na esfera municipal, subsidiando a rede pública de fiscalização ${ }^{8}$ com o monitoramento dos processos de cadastramento, seleção de beneficiários, concessão e manutenção dos benefícios e do controle das condicionalidades.

Considera-se produto do PBF o cumprimento das condicionalidades ${ }^{9}$ exigidas para a concessão dos benefícios. As pessoas entre sete e 15 anos integrantes de famílias beneficiárias devem ter freqüência escolar mínima de $85 \%$. As gestantes devem comparecer a exames prénatais e participar de atividades educativas sobre aleitamento materno e orientação alimentar. As nutrizes e responsáveis por crianças entre seis meses e seis anos devem cumprir o calendário vacinal das crianças, levá-las à unidade de saúde para acompa- nhamento do crescimento e desenvolvimento e participar de atividades educativas sobre alimentação, aleitamento materno e cuidados gerais com a saúde da criança.

O MDS responsabiliza-se pelo apoio, pela articulação intersetorial e pela supervisão das ações governamentais para o cumprimento das condicionalidades do PBF, bem como pela disponibilização da base atualizada do Cadastro Único aos Ministérios da Educação e da Saúde.

Os responsáveis pelo acompanhamento e fiscalização do cumprimento dessas condicionalidades são o Ministério da Saúde, no que diz respeito ao acompanhamento do crescimento e desenvolvimento infantil, da assistência ao pré-natal e ao puerpério, da vacinação, bem como da vigilância alimentar e nutricional de crianças menores de sete anos; e o Ministério da Educação, no que diz respeito à freqüência mínima de $85 \%$ da carga horária escolar

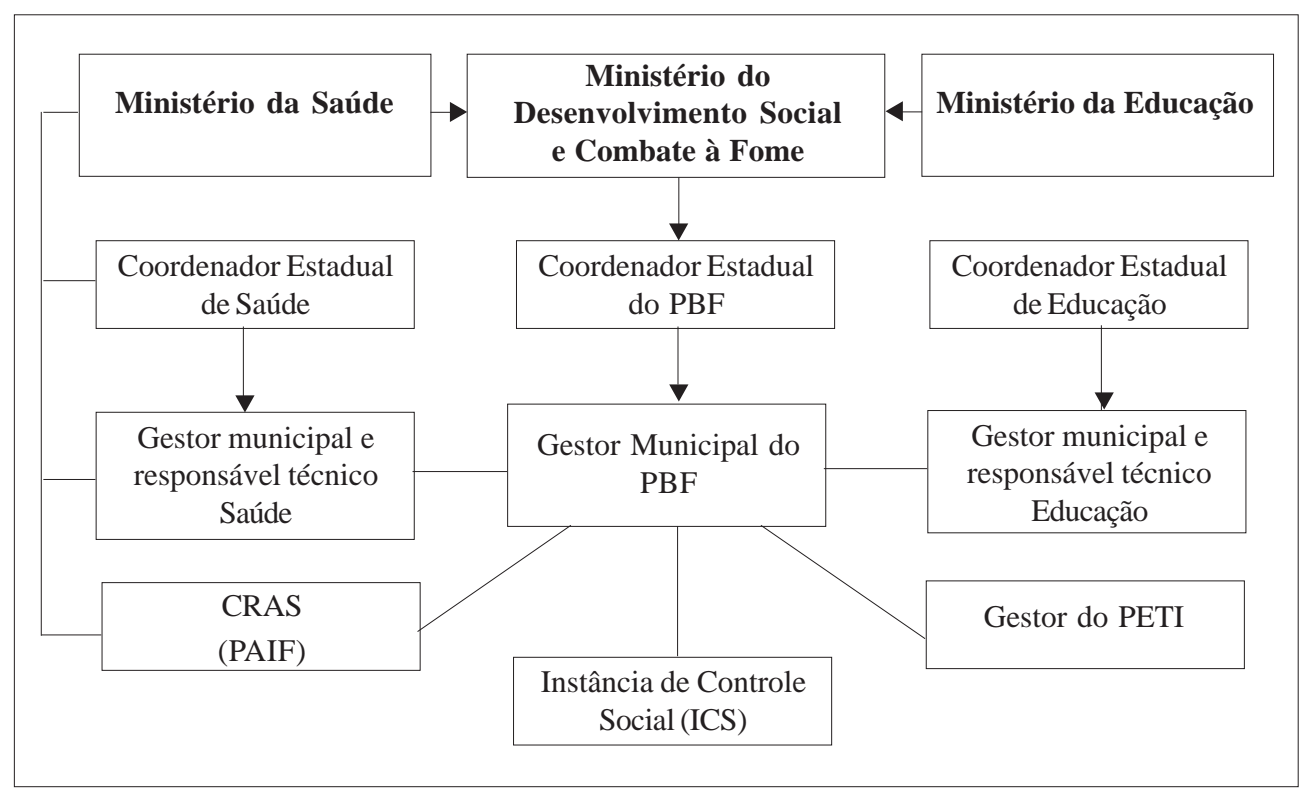

Figura 1: Arranjo institucional para a gestão do acompanhamento das condicionalidades do Programa Bolsa Família 
mensal, em estabelecimentos de ensino regular, de crianças e adolescentes de seis a 15 anos.

Entre outras coisas, compete ao Ministério da Saúde designar a Secretaria de Atenção Básica da Saúde como a área técnica responsável pela gestão federal do acompanhamento do cumprimento das condicionalidades de saúde das famílias beneficiárias. Compete ao Ministério da Educação, no Programa Bolsa Família, indicar a área técnica responsável pela gestão federal do sistema de freqüência escolar dos alunos.

Os estados, o Distrito Federal e os municípios que dispuserem das condições técnicas e operacionais para a gestão do acompanhamento das condicionalidades do PBF poderão exercer essa atribuição, segundo as normas do programa.

São responsabilidades das famílias atendidas no PBF:

- para as gestantes e nutrizes, no que couber: inscrever-se no pré-natal e comparecer às consultas na unidade de saúde mais próxima de sua residência, portando o cartão da gestante, de acordo com o calendário mínimo preconizado pelo Ministério da Saúde; participar de atividades educativas ofertadas pelas equipes de saúde sobre aleitamento materno e promoção da alimentação saudável;

- para os responsáveis pelas crianças e pelos adolescentes menores de sete anos: levar a criança à unidade de saúde ou ao local de campanha de vacinação, mantendo em dia o calendário de imunização, conforme preconizado pelo Ministério da Saúde; levar a criança às unidades de saúde, portando o cartão de saúde da criança, para a realização do acompanhamento do estado nutricional e do desenvolvimento e de outras ações, conforme o calendário mínimo preconizado pelo Ministério da Saúde;
- informar ao órgão municipal responsável pelo Cadastramento Único qualquer alteração no seu cadastro original, objetivando a atualização do cadastro da sua família.

A União, os estados, o Distrito Federal e os municípios deverão informar e orientar as famílias sobre os seus direitos e responsabilidades no $\mathrm{PBF}$ e sobre a importância da freqüência aos serviços de saúde para a melhoria das condições de saúde e nutrição de seus membros.

As famílias beneficiárias com gestantes, nutrizes e crianças menores de sete anos de idade deverão ser assistidas por uma equipe de saúde da família, por agentes comunitários de saúde ou por unidades básicas de saúde, que proverão os serviços necessários ao cumprimento das ações de responsabilidade da família.

As Secretarias Municipais de Saúde e as Secretarias Estaduais de Saúde, cada qual na sua esfera, devem, entre outras coisas, indicar um responsável técnico - profissional de saúde - para coordenar o acompanhamento das famílias do PBF, no âmbito da saúde.

Cabe ao poder público a oferta de serviços de educação com acompanhamento da freqüência escolar dos alunos. Definem-se para o responsável legal das famílias atendidas pelo PBF as seguintes responsabilidades:

- efetivar, observada a legislação escolar vigente, a matrícula escolar em estabelecimento regular de ensino;

- garantir a freqüência escolar de, no mínimo, $85 \%$ da carga horária mensal do ano letivo;

- informar imediatamente à escola, quando da impossibilidade de comparecimento do aluno à aula, apresentando, se existente, a devida justificativa da falta. 
A freqüência escolar deverá ser apurada mensalmente pelos estabelecimentos regulares de ensino para verificação do índice mínimo de $85 \%$ da carga horária mensal. Os responsáveis pelo acompanhamento das condicionalidades relativas à escolaridade são os dirigentes dos estabelecimentos de ensino que contarem com alunos beneficiários do $\mathrm{PBF}$.

$O$ gestor do sistema de freqüência escolar no município deverá ser o titular do órgão municipal de Educação, cujas atribuições incluem a de integrar a Coordenação Municipal do PBF. O gestor do sistema de freqüência escolar no estado deverá ser o titular da Secretaria Estadual de Educação, cujas atribuições incluem a de integrar a Coordenação Estadual do PBF.

As ações de gestão de condicionalidades compreendem: o acompanhamento periódico das ações nas áreas de saúde e educação que as famílias devem realizar; o registro das informações do acompanhamento das condicionalidades nos sistemas disponibilizados pelo MDS, MEC e MS; a repercussão gradativa referente ao descumprimento de condicionalidades.

A gestão de benefícios do PBF abrange um conjunto de atividades executadas pelos municípios e pela Senarc/ $\mathrm{MDS}^{10}$, entre as quais se destaca a atividade de bloqueio de benefícios das famílias do PBF, cabível em qualquer uma das seguintes situações:

- trabalho infantil na família;

- durante procedimento de averiguação de cadastramento, quando houver indícios de duplicidade cadastral; renda per capita familiar superior à estabelecida para o PBF; falecimento de toda a família; ou não localização da família no endereço informado no CadÚnico;
- durante o procedimento de averiguação de acúmulo de benefícios financeiros do PBF com os do PETI;

- por decisão judicial; ou

- por descumprimento de condicionalidades do PBF, observada a legislação vigente.

$O$ bloqueio de benefícios financeiros implicará o impedimento da retirada das parcelas de pagamento ainda não sacadas pela família e o impedimento do saque das parcelas de pagamento dos meses

$\quad$ "A imprecisão
conceitual [sobre
trabalho infantil]
soma-se aos fatores
culturais para impor
óbices à
sustentabilidade
da política de
erradicação do
trabalho infantil
dentro do próprio
poder público."

subseqüentes até o desbloqueio, se for o caso. $O$ bloqueio do benefício financeiro não implica, por si só, o desligamento da família do PBF. Porém, decorrido o prazo máximo de seis meses, os benefícios financeiros que ainda permanecerem bloqueados pelos motivos acima definidos serão automaticamente cancelados, salvo disposição em contrário da Senarc. 
$\mathrm{Na}$ ocorrência de descumprimento de condicionalidades, o bloqueio ou a suspensão de benefício das famílias do PBF é atribuição exclusiva da Senarc, observada a norma específica, tendo por base as informações sobre condicionalidades do PBF encaminhadas pelos municípios, conforme o caso, aos Ministérios da Saúde ou da Educação. Não serão punidas com suspensão ou cancelamento do benefício as famílias que não cumprirem as condicionalidades previstas, quando não houver a oferta do respectivo serviço, ou por força maior ou caso fortuito.

A família beneficiária do PBF em situação de trabalho infantil permanecerá com benefícios financeiros bloqueados até a cessação do trabalho infantil, admitidas outras providências previstas na regulamentação da política de erradicação do trabalho infantil, nos termos da Lei.

Por intermédio da Portaria 360, de 2005, estabeleceu-se que o MDS transferiria recursos do FNAS aos municípios, para que estes realizassem ações de cadastramento e de atualização das bases de dados dos seus cidadãos incluídos no CadÚnico. A adesão do município ao PBF e ao CadÚnico nos termos da Portaria GM/MDS nํ2 246, de 20 de maio de 2005, foi a condição estabelecida para o recebimento de recursos financeiros destinados ao desenvolvimento de sua capacidade de gestão do Programa Bolsa Família e do Cadastro Único de programas sociais.

Desde os seus primeiros anos de implantação, o Cadastro Único vem sendo objeto de periódicas avaliações devido à sua centralidade para os programas sociais e à persistência dos problemas que apresenta. Em auditoria operacional realizada em 2002, o TCU já apontava distorções relativas à unicidade dos registros e a outras dimensões. As principais falhas detectadas no CadÚnico são:

- duplicidade cadastral;

\section{Quadro 2: Descumprimento de condicionalidades}

\begin{tabular}{|l|l|l|l|}
\hline Descumprimento & Sanção & Notificação & Observação \\
\hline $1^{\circ}$ Registro & Não & Sim & $\begin{array}{l}\text { Sem efeito sobre o } \\
\text { beneficio }\end{array}$ \\
\hline $2^{\circ}$ Registro & Bloqueio por 30 dias & Sim & $\begin{array}{l}\text { Subseqüente } \\
\text { desbloqueio }\end{array}$ \\
\hline $3^{\circ}$ e $4 \circ$ Registros & Suspensão por 60 dias & Sim & $\begin{array}{l}\text { Sem pagamento } \\
\text { das parcelas }\end{array}$ \\
\hline $5 \circ$ Registro & Cancelamento & Sim & Desligamento \\
\hline
\end{tabular}

Fonte: MDS. Portaria no 551, de 09 de novembro de 2005

Tabela 1: Notificação por descumprimento de condicionalidades: Brasil - agosto e setembro de 2006 - números absolutos

\begin{tabular}{|l|l|l|l|}
\hline & Municípios & Advertências & Bloqueios \\
\hline Brasil & 3.410 & 172.268 & 219 \\
\hline
\end{tabular}

Fonte: Senarc/MDS 
- distorções na estratégia de seleção de famílias cadastradas;

- informações prestadas divergentes das registradas;

- famílias com evidências de renda superior ao limite estabelecido;

- não realização de visitas para confirmação dos dados declarados pelas familias;

- guarda e armazenamento inseguro dos formulários;

- grande proporção de cadastramento de servidores municipais;

- priorização do cadastramento de famílias residentes nas áreas urbanas dos municípios;

- famílias não localizadas;

- famílias beneficiadas, sem a posse do cartão social.

$O$ processo de controle do $\mathrm{PBF}$ compreende duas vertentes:

1) Ações internas de controle, que consistem em:

Fiscalização: exame amplo dos processos de trabalho, do modelo de execução, consistência dos cadastros e das informações enviadas ao PBF.

Vistoria: esclarecimento de denúncias de irregularidades recebidas pela central de atendimento, pela Controladoria-Geral da União (CGU), TCU, Ministério Público Federal (MPF), Ministério Público Estadual (MPE), Instância de Controle Social (ICS) do Departamento de Operação, Coordenação Geral e Fiscalização do MDS etc.

Acompanhamento a distância: obtenção e exame de dados a distância, para comparação com registros e dados do $\mathrm{PBF}$.

Monitoramento: executado de maneira a aproveitar os deslocamentos das equipes de fiscalização e vistoria, à região próxima da localidade cujo programa deva ser monitorado.

2) Ações externas de controle, que consistem em:
Recebimento, tratamento e apuração das denúncias oriundas da sociedade.

Fornecimento de dados e informações (relatórios e pareceres) aos gestores municipais e aos órgãos que compõem a rede pública de fiscalização, para implementação de providências no âmbito de suas competências.

Tratamento das falhas e disfunções apuradas por fiscalizações da CGU, relativas aos sorteios públicos.

Apurações - in loco e a distância - de falhas na execução do PBF e dos programas remanescentes.

\section{A integração do PETI-PBF}

A integração entre o Programa de Erradicação do Trabalho Infantil e o Programa Bolsa Família foi estabelecida pela Portaria 666, de 28 de dezembro de 2005, com os objetivos de:

- racionalizar e aprimorar os processos de gestão do PBF e do PETI, pela universalização da obrigatoriedade de pagamento do benefício por meio de cartão magnético da CAIXA e pela inclusão de todas as famílias no CadÚnico;

- ampliar a cobertura do atendimento de crianças e adolescentes em situação de trabalho infantil do PETI, com a inclusão de crianças menores de seis anos;

- estender as ações socioeducativas e de convivência do PETI para crianças e adolescentes do PBF em situação de trabalho infantil; e

- promover a universalização do PBF para as famílias que atendem aos seus critérios de elegibilidade.

De acordo com a Portaria 666/2005 ${ }^{11}$, para o processo de integração ficou definido que: 
- o componente de transferência de renda para as famílias que atendam ao critério de elegibilidade do PBF será tido como benefício financeiro do PBF, representando, junto com o Cadastro Único, a principal ação desse programa;

- o componente de transferência de renda para as famílias que não atendam ao critério de elegibilidade do PBF será tido como benefício financeiro do PETI, que se transformou em uma categoria residual do PETI;

- o componente de ações socioeducativas e de convivência que devem ser freqüentadas pelas crianças e pelos adolescentes das famílias oriundas do PETI, assim como pelas famílias beneficiárias do PBF que apresentem situação de trabalho infantil, será tido como parte integrante do PETI, tornando-se a sua principal ação finalística.

\section{Quanto à transferência de renda}

Observado o disposto nos artigos de 4ํ a 8o, da Portaria 666, de 2005, a análise das diferentes situações existentes entre os beneficiários mostra um conjunto de novas categorias (Quadro 3) ${ }^{12}$. Por sua vez, a definição dessas novas categorias de famílias beneficiárias apresentou as seguintes resultantes:

- Para as famílias enquadradas na categoria 1: família egressa do PETI/CAIXA, com renda per capita de até $\mathrm{R} \$ 60,00$, teria vantagem em ser transferida para o $\mathrm{PBF}$ somente se fosse residente em zona rural ou município com menos de $250 \mathrm{mil}$ habitantes; recebesse a soma do benefício fixo mais o benefício variável por ser enquadrada na categoria de "renda per capita até $\mathrm{R} \$ 60,00$ ”13; tivesse até três crianças ou adolescentes em situação de trabalho infantil. A partir da quarta criança ou adolescente em situação de trabalho infantil a transferência do PETI para o PBF tornase desvantajosa.

No caso das famílias residentes em zona urbana, somente se: recebesse a soma do benefício fixo mais o benefício variável por ser enquadrada na categoria de "renda per capita até $\mathrm{R} \$ 60,00^{14 \prime \prime}$; tiver apenas uma criança ou adolescente em situação de trabalho infantil.

- Para famílias egressas do PETI que se enquadram nas categorias 2, 3 e 4: do ponto de vista do valor do benefício, a integração praticamente não traz nenhuma conseqüência.

- Para novas familias beneficiárias: somente haveria estímulo à retirada de crianças/ adolescentes do trabalho infantil para as que se enquadrassem na categoria 5 , quais sejam: famílias que têm renda per capita acima de $R \$ 120,00$, para as quais está previsto o benefício PETI/CAIXA.

Esse benefício, porém, está condicionado a que haja "meta disponível", ou seja, recursos para esse fim. Como a ação de transferência de renda do PETI assumiu uma condição absolutamente secundária e residual, é pouco provável que, no futuro, essa categoria continue existindo.

- Para as novas famílias com renda per capita de até $\mathrm{R} \$ 60,00$ ou entre $\mathrm{R} \$ 60,01 \mathrm{e}$ $\mathrm{R} \$ 120,00$ - categorias 6, 7, 8 e 9 -, que irão receber benefício PBF: não há tratamento diferenciado caso tenham crianças e adolescentes em situação de trabalho infantil, o que pode obstar o incentivo ao afastamento dessa situação.

\section{Quanto ao registro do trabalho infantil}

Os gestores entrevistados no MDS expressaram o entendimento de que a ausência de um incentivo específico não prejudicará a política de combate ao 
Quadro 3: Programa de destino e tipo de benefício por categorias de famílias na integração PETI-PBF (Portaria 666/2005)

\begin{tabular}{|c|c|c|c|c|}
\hline $\begin{array}{l}\text { Categorias de } \\
\text { familias }\end{array}$ & $\begin{array}{l}\text { Característica } \\
\text { específica }\end{array}$ & $\begin{array}{l}\text { Critério de } \\
\text { elegibilidade: } \\
\text { renda per } \\
\text { capita }\end{array}$ & $\begin{array}{l}\text { Programa } \\
\text { de destino }\end{array}$ & Tipo de benefício \\
\hline $\begin{array}{l}\text { 1. Egressas do } \\
\text { PETI }\end{array}$ & $\begin{array}{l}\text { Recebiam } \\
\text { PETI/CAIXA }\end{array}$ & Até RS 120,00 & PBF & $\begin{array}{l}\text { Se a renda per capita for até } \mathrm{R} \$ 60,00 \text {, } \\
\text { faz jus ao básico + variável } \\
\text { (limite de de R\$ } 95,00 \text { ). } \\
\text { Se for de } \mathrm{R} \$ 60,01 \text { até } \mathrm{R} \$ 120,00 \text {, } \\
\text { somente faz jus ao beneficio variável } \\
\text { (limite de R\$ } 45,00 \text { ). }\end{array}$ \\
\hline $\begin{array}{l}\text { 2. Egressas do } \\
\text { PETI }\end{array}$ & $\begin{array}{l}\text { Só possuíam PETI } \\
\text { e a migração para o } \\
\text { PBF reduzirá o } \\
\text { beneficio }\end{array}$ & Até R\$ 120,00 & PETI/CAIXA & $\begin{array}{l}\text { Permanecem com o mesmo valor que } \\
\text { vinham recebendo no PETI. }\end{array}$ \\
\hline $\begin{array}{l}\text { 3. Egressas do } \\
\text { PETI }\end{array}$ & $\begin{array}{l}\text { Recebiam } \\
\text { PETI/FUNDO } \\
\end{array}$ & $\begin{array}{l}\text { Maior que RS } \\
120,00\end{array}$ & PETI/CAIXA & $\begin{array}{l}\text { Permanecem com o mesmo valor que } \\
\text { vinham recebendo no PETI. }\end{array}$ \\
\hline $\begin{array}{l}\text { 4. Egressas do } \\
\text { PETI }\end{array}$ & $\begin{array}{l}\text { Recebiam } \\
\text { PETI/FUNDO }\end{array}$ & Até R\$ 120,00 & PBF & $\begin{array}{l}\text { Se a renda per capita for até R\$ } \\
60,00 \text {, faz jus ao básico + variável } \\
\text { (limite de R\$ } 95,00 \text { ). } \\
\text { Se for de R\$ } 60,01 \text { até R\$ } 120,00 \text {, } \\
\text { somente faz jus ao beneficio variável } \\
\text { (limite de R\$ } 45,00 \text { ). } \\
\text { Em ambos os casos se a familia tiver } \\
\text { Beneficio de Programas } \\
\text { Remanescentes, exceto Bolsa } \\
\text { Escola Federal, e ao migrar, ocorrerá } \\
\text { redução do beneficio, receberá a } \\
\text { complementação de um Beneficio } \\
\text { variável de caráter extraordinário. }\end{array}$ \\
\hline $\begin{array}{l}\text { 5. Novas, com } \\
\text { trabalho } \\
\text { infantil }\end{array}$ & $+\cdots$ & $\begin{array}{l}\text { Maior que RS } \\
120,00\end{array}$ & PETI/CAIXA & $\begin{array}{l}\text { O ingresso no PETI dependerá da } \\
\text { Existência de meta disponível. }\end{array}$ \\
\hline $\begin{array}{l}\text { 6. Novas, com } \\
\text { trabalho } \\
\text { infantil }\end{array}$ & $+\cdots$ & Até RS 60,00 & PBF & Fixo+Variável até o teto de R\$ 95,00 . \\
\hline $\begin{array}{l}\text { 7. Novas, com } \\
\text { trabalho } \\
\text { infantil }\end{array}$ & $+\cdots$ & $\begin{array}{l}\text { Entre R\$60,01 e } \\
\text { R\$120,00 }\end{array}$ & PBF & Variável, até o teto de $\mathrm{R} \$ 45,00$. \\
\hline $\begin{array}{l}\text { 8. Novas, sem } \\
\text { trabalho } \\
\text { infantil }\end{array}$ & -..- & Até RS 60,00 & PBF & $\begin{array}{l}\text { Fixo+ Variável, até o teto de R } \$ 95,00 \\
\text { (se a cobertura do PBF no municipio } \\
\text { não ultrapassou } 100 \% \text { ). }\end{array}$ \\
\hline $\begin{array}{l}\text { 9. Novas, sem } \\
\text { trabalho } \\
\text { infantil }\end{array}$ & $\cdots$ & $\begin{array}{l}\text { Entre R\$60,01 e } \\
\text { R\$120,00 }\end{array}$ & PBF & $\begin{array}{l}\text { Variável, até o teto de R\$ } 45,00 \text { (se a } \\
\text { cobertura do PBF no municipio não } \\
\text { ultrapassou } 100 \% \text { ). }\end{array}$ \\
\hline
\end{tabular}

Tabela 2: Comparação simulada dos benefícios PETI e PBF, segundo o número de crianças ou adolescentes em trabalho infantil

\begin{tabular}{c|c|c|c|c}
\hline \multirow{2}{*}{$\begin{array}{c}\text { Número de } \\
\text { criança/ ou } \\
\begin{array}{c}\text { adolescentes } \\
\text { em trabalho } \\
\text { infantil }\end{array}\end{array}$} & $\begin{array}{c}\text { Zona rural e } \\
\text { zona urbana } \\
\text { com menos de } \\
250 \text { mil hab. }\end{array}$ & $\begin{array}{c}\text { Zona urbana } \\
\text { com mais de } \\
250 \text { mil hab. }\end{array}$ & $\begin{array}{c}\text { Renda per } \\
\text { capita de até } \\
\mathrm{R} \$ 60,00^{*}\end{array}$ & $\begin{array}{c}\text { Renda per capita } \\
\text { entre } \mathrm{R} \$ 60,01 \mathrm{e} \\
\mathrm{R} \$ 120,00\end{array}$ \\
\hline 01 & $\mathrm{R} \$ 25,00$ & $\mathrm{R} \$ 40,00$ & $\mathrm{R} \$ 65,00$ & $\mathrm{R} \$ 15,00$ \\
\hline 02 & $\mathrm{R} \$ 50,00$ & $\mathrm{R} \$ 80,00$ & $\mathrm{R} \$ 80,00$ & $\mathrm{R} \$ 30,00$ \\
\hline 03 & $\mathrm{R} \$ 75,00$ & $\mathrm{R} \$ 120,00$ & $\mathrm{R} \$ 95,00$ & $\mathrm{R} \$ 45,00$ \\
\hline 04 & $\mathrm{R} \$ 100,00$ & $\mathrm{R} \$ 160,00$ & - & - \\
\hline
\end{tabular}

(*)Este é um dos critérios de discriminação das familias para definição do benefício a ser pago, mas não se encontra especificamente mencionado no Art. $7^{2}$ da Portaria 666/2005. 
trabalho infantil na medida em que "(...) em todos os benefícios existe uma restrição ao trabalho infantil, e isso é uma restrição de fato e não uma regra de entrada ou uma condicionalidade".

Entretanto, para que essa restrição seja observada, a situação de trabalho infantil deve ser informada, constatada, registrada. E, como a própria experiência vem ensinando, o principal obstáculo no combate ao trabalho infantil é a omissão dessa informação, que é reconhecida quando o gestor da área da assistência social admite haver "(...) famílias que recebiam pelo PETI/Fundo e ao se cadastrarem no PBF não informaram o campo 270, que caracteriza a situação de trabalho infantil".

Para a política de combate ao trabalho infantil, o problema do registro da informação talvez seja um dos mais preocupantes do processo de integração via CadÚnico, especialmente quando se tem em vista o que se segue:

- o cadastramento é de responsabilidade do órgão da prefeitura municipal, mediante o preenchimento de um caderno de questionários aplicados por um entrevistador;

- o caderno de questionários contém três tipos de instrumentos, referentes à "identificação do domicílio e da família"; cinco jogos para "identificação da pessoa"; e dois jogos para "identificação do agricultor familiar";

- não existe, em nenhum dos três instrumentos, uma única pergunta explicitamente direcionada à existência de crianças e adolescentes em situação de trabalho infantil;

- no questionário de "identificação do agricultor familiar", no bloco 4, solicita-se que o entrevistado descreva a força de trabalho "além da familiar" "15, indagandose sobre a contratação de trabalhadores eventuais e permanentes e sobre a administração do estabelecimento. Nesse questionário não há uma única pergunta sobre a idade dos membros da força de trabalho familiar ou dos demais trabalhadores;

- no questionário de "identificação da pessoa" há um bloco de perguntas sobre a situação no mercado de trabalho, com as categorias convencionais do trabalho adulto; nome da empresa, CNPJ e data de admissão; ocupação; remuneração, renda de aposentadoria ou de pensão, renda de seguro desemprego e de pensão alimentícia, entre outras.

- nesse mesmo questionário há o "campo 270", em que o entrevistado deve informar se participa de algum programa do governo federal ou recebe algum benefício social, entre os quais se encontra listada a categoria "Bolsa Criança Cidadã PETI", com a data de inclusão, o tipo de benefício (rural ou urbano) e o valor do benefício ${ }^{16}$. Os gestores do CadÚnico acreditam que os entrevistados informarão caso sejam beneficiários de algum dos programas do campo 270 , e que a informação sobre o recebimento de benefício na categoria "Bolsa Criança Cidadã PETI” permitirá identificar as situações de trabalho infantil.

A omissão da informação também é descrita na área de fiscalização do trabalho: "Não interessa às famílias que as crianças e os adolescentes deixem de trabalhar. Se o trabalho ocorre no ambiente doméstico ou familiar, os pais recebem a bolsa e a criança continua trabalhando".

Os próprios setores responsáveis pela identificação e pelo mapeamento do trabalho infantil consideram esta uma tarefa particularmente difícil. Primeiramente, porque o trabalho infantil ocorre, na grande maioria das vezes, fora dos empreendimentos formalmente estabelecidos ${ }^{17}$, que 
são o foco privilegiado da ação das DRTs. Em outras palavras, é escassa a ocorrência do trabalho infantil na economia formal. No entanto, a prática é comum na economia informal, mas só assume visibilidade quando realizada nos espaços públicos: lixões, semáforos nas cidades (onde crianças e adolescentes vendem balas, frutas, panos de pratos etc.). Segundo, porque excetuando a agricultura familiar, as atividades realizamse no espaço doméstico, ou como trabalho doméstico propriamente dito ou como trabalho familiar artesanal, e a ação do MTE não alcança esse lócus ${ }^{18}$.

De fato, como informou um dos entrevistados, a ação do MTE/DRT tem que cessar diante da porta de entrada dos domicílios particulares. Daí por diante o que cabe é a ação do Ministério Público do Trabalho (MPT), que vem atuando em parceria com a SNAS.

Por último, mas não menos importante, o sub-registro do trabalho infantil resulta do fato de que o próprio entendimento do conceito de trabalho infantil entre as autoridades na esfera municipal não é consensual e nem os critérios usados são uniformes. Os entrevistados reconhecem que esse é outro esforço que deve ser feito: uma definição mais precisa do que é o trabalho infantil.

A imprecisão conceitual soma-se aos fatores culturais para impor óbices à sustentabilidade da política de erradicação do trabalho infantil dentro do próprio poder público. $O$ exemplo mais preocupante e mais recente encontra-se na Lei $\mathrm{n}^{\mathrm{o}}$ 11.326, de 24 de julho de 2006, que estabelece os conceitos, os princípios e os instrumentos destinados à formulação das políticas públicas direcionadas à agricultura familiar e aos empreendimentos familiares rurais. $\mathrm{O}$ artigo $3^{\circ}$ dessa lei define como agricultor familiar e empreendedor familiar rural aquele que, entre outras coisas, utilize predominantemente mão-de-obra da própria família nas atividades econômicas do seu estabelecimento ou empreendimento; e dirija seu estabelecimento ou empreendimento com sua família".

O texto legal é completamente omisso com relação a qualquer restrição ao trabalho infantil ou à previsão de qualquer condição, mecanismo ou ação fiscalizatória, destinada a coibir a exploração da mão-de-obra infantil na agricultura, exatamente um dos setores de atividade econômica em que a prática é mais freqüente.

O reconhecimento de que existe um problema efetivo de identificação do trabalho infantil e dos limites do CadÚnico para solucionar esse problema levou o MDS a contratar, com o Instituto Brasileiro de Geografia e Estatística (IBGE), um suplemento da Pnad/2007 voltado para o trabalho infantil, a fim de chegar à identificação dos estimados cinco milhões de crianças e adolescentes em situação de trabalho infantil.

O conjunto de mudanças implementadas durante o ano de 2006 evidencia o fato de que a política governamental efetivamente substituiu o critério do trabalho infantil pelo critério de renda. Essa medida não se mostra consistente com os esforços de combate ao trabalho infantil, que é reconhecidamente um fenômeno complexo, envolvendo as dimensões tanto da pobreza e da renda familiar, quanto da cultura e da dinâmica do mercado, entre outras.

\section{Ações socioeducativas e de convivência}

No que se refere à política de combate ao trabalho infantil especificamente considerada, a ação governamental passou a ter como foco as ações socioeducativas e de convivência, anteriormente denominadas "jornada ampliada", o que aparentemente 
significa uma ênfase no trato da dimensão sociocultural do trabalho infantil. Essa mudança fica evidenciada na análise da distribuição dos recursos alocados ao PETI e ao PBF (Tabela 3).

Do ponto de vista orçamentário, com a integração, os recursos do PETI destinados à transferência de renda diminuíram drasticamente, saindo de mais de $\mathrm{R} \$ 300$ milhões para cerca de $\mathrm{R} \$ 50$ milhões, ou seja, uma redução de quase $85 \%$.

Já os valores alocados às ações socioeducativas e de convivência foram aumentados, mas não na proporção correspondente: saíram de quase $\mathrm{R} \$ 206$ milhões, em 2005, para pouco mais de R\$306 milhões, em 2006, com aumento de $48 \%$, que em 2007 chegou a 54\%.

De acordo com a Portaria 666, de 2005, as ações socioeducativas e de convivência deveriam ser estendidas a crianças e adolescentes das famílias beneficiárias do PBF em situação de trabalho infantil. Ou seja, essa atividade deveria ter se intensificado. Mas não foi o que ocorreu. Como mostra a Tabela 3, o valor pago em 2006 ficou em torno de $65 \%$, ou seja, $2 / 3$ do valor autorizado.

Em parte, isso ocorreu porque não foi possivel inscrever no Cadúnico todas as crianças, os adolescentes e as famílias que eram anteriormente beneficiárias do PETI: estimava-se 1,1 milhão e foram inscritos 862.700 crianças e adolescentes. Mas o dado é preocupante: o valor absoluto executado em 2006 foi em torno de R\$198 milhões. Ou seja: menor não apenas que o valor expandido para o atendimento das crianças e dos adolescentes do PETI somado às crianças e aos adolescentes em situação de trabalho infantil incorporadas como beneficiárias do PBF (R \$ 306 milhões) e somado ao atendimento às crianças abaixo de seis anos, mas abaixo até mesmo do valor executado em 2005, relativo estritamente às crianças e aos adolescentes beneficiários do PETI.

Uma explicação, segundo um dos gestores entrevistados, está no fato de que “(...) quando se fez a migração, observouse que $3 / 4$ das crianças e adolescentes de famílias que recebiam PBF estavam em situação de trabalho infantil, recebendo também pelo PETI", o que significaria um problema de duplicidade no Cadastro e não de subexecução das ações socioeducativas e de convivência.

Segundo foi apurado junto aos entrevistados, o MDS havia se preparado para cumprir, em 2006, a meta de atender 3,5 milhões de crianças e adolescentes com ações socioeducativas e de convivência, o que não ocorreu devido aos transtornos do processo de migração. Cabe chamar a atenção, porém, para o fato de que, de acordo com a Portaria 666, de 2005, Art. 15, a SNAS promoverá a oferta de atividades socioeducativas e de convivência para as famílias em situação de trabalho infantil beneficiárias do PBF ou usuárias do PETI, por meio dos municípios que formam a rede de implementação do PETI, havendo disponibilidade orçamentário-financeira.

Isso faz com que seja ainda mais importante que o Fórum Nacional e as agências da sociedade comprometidas com a erradicação do trabalho infantil acompanhem a formulação e a votação do Plano Plurianual, da Lei de Diretrizes Orçamentárias e da Lei Orçamentária anual, bem como o detalhamento das metas de custeio das ações socioeducativas e de convivência, cujos recursos devem ser previstos no Fundo Nacional de Assistência Social.

Outro aspecto que merece especial atenção são os problemas recorrentes com 
Tabela 3: Valor autorizado para execução das ações finalísticas do PETI e do PBF e do Cadastro Único, por ano, 2005-2007

\begin{tabular}{|l|c|c|c}
\hline \multirow{2}{*}{ Ação } & \multicolumn{3}{|c}{$\begin{array}{c}\text { Lei + créditos } \\
\text { (valor autorizado) }\end{array}$} \\
\cline { 2 - 4 } & $\mathbf{2 0 0 5}$ & $\mathbf{2 0 0 6}$ & $\mathbf{2 0 0 7}$ \\
\hline $\begin{array}{l}\text { PETI-Bolsa } \\
\text { Ação 09JB }\end{array}$ & $\begin{array}{l}329.561 .317 \\
(99,05 \%)\end{array}$ & $\begin{array}{c}51.767 .531 \\
(88,30 \%)\end{array}$ & 58.750 .000 \\
\hline $\begin{array}{l}\text { PETI-Ações socioeducativas } \\
\text { Ação 2060 }\end{array}$ & $\begin{array}{l}205.853 .685 \\
(97,86 \%)\end{array}$ & $\begin{array}{c}306.028 .034 \\
(64,57 \%)\end{array}$ & 316.346 .529 \\
\hline $\begin{array}{l}\text { Bolsa-Família - Transferência de renda } \\
\text { Ação 0060+099A }\end{array}$ & 5.392 .610 .777 & 8.328 .500 .000 & 8.605 .200 .000 \\
\hline $\begin{array}{l}\text { Cadastro Único } \\
\text { Ação 6414 }\end{array}$ & 7.200 .000 & 21.860 .345 & 21.147 .328 \\
\hline
\end{tabular}

(*) Percentual correspondente à execução: valores pagos

Fonte: SIDOR

a realização das ações socioeducativas e de convivência. Em grande parte, esse aspecto é conseqüência da ausência de definição precisa do que devem ser tais ações. Segundo foi apurado nas entrevistas com os gestores, “(...) falta definir parâmetros para as ações socioeducativas e de convivência, pois não há modelo; cada um faz o que quer".

E atualmente: "Estão sendo trabalhadas as diretrizes pedagógicas para as ações socioeducativas e de convivência, que devem atingir as crianças e os adolescentes em geral. Essas diretrizes vão compor a segunda versão do 'Guia de orientação técnica de proteção social básica’ para desenvolver as potencialidades de crianças e adolescentes. Em seguida será feita uma capacitação por meio de educação a distância (EAD) para operadores do PETI, PBF e Centro de Referência de Assistência Social (CRAS), sendo um dos módulos dessa capacitação, justamente, a prestação das ações socioeducativas e de convivência para crianças e adolescentes.

Vale observar, porém, que já no início de 2006, portanto há um ano, o Departamento de Proteção Social Especial (DPSE) informava que uma proposta pedagógica para as ações socioeducativas e de convivência está em processo de elaboração ${ }^{19}$.

Outro problema diz respeito à ineficácia do controle sobre a prestação das ações socioeducativas e de convivência para crianças e adolescentes. A SNAS paga aos municípios um valor por criança ou adolescente atendido com essas ações, atualmente, em R\$20,00. Segundo informaram os entrevistados, “(...) quando foi suspenso o repasse fundo-a-fundo, os municípios não se queixaram de perder o controle da bolsa, mas sim os recursos para as ações socioeducativas e de convivência, porque o (valor) per capita pago pelo PETI, de $\mathrm{R} \$ 20,00$, é o mais alto de todos os programas no País (...). Os dados das auditorias mostram que, na realidade, essas ações não eram oferecidas, e isso era possível porque a prestação de contas não era transparente. Como não havia controle, os municípios usavam o dinheiro e não realizavam as ações. Mas cabe perguntar: se os gestores não as realizavam ou subexecutavam, onde ficam as instâncias de controle?".

Essa é uma pergunta da maior relevância diante da centralidade assumida pelas ações socioeducativas e de convivência para 
o combate ao trabalho infantil. Do ponto de vista do controle social, a Portaria 666, de 2005, estabelece em seu artigo 18 que "caberão à instância municipal de controle social do PBF, sem detrimento de outras responsabilidades, as seguintes atribuições:

- comunicar aos gestores municipais do PBF e do PETI os casos de famílias beneficiárias do PBF em situação de trabalho infantil em sua localidade;

- manter interlocução com a Comissão Municipal de Erradicação do Trabalho Infantil; e

- comunicar aos gestores municipais do PBF e do PETI a respeito de famílias que recebam recursos desses programas que não estejam respeitando a freqüência às ações socioeducativas e de convivência, sobre a inexistência ou precariedade da oferta dessas ações no âmbito local".

A precariedade do controle exercido por essas instâncias sobre o objeto central de sua responsabilidade - o PBF - está amplamente documentada nas auditorias realizadas, inclusive pelo TCU. Torna-se difícil, assim, alimentar expectativas realistas de que elas sejam capazes de absorver também as responsabilidades relativas ao trabalho infantil, especialmente quando o foco é a oferta e freqüência às ações socioeducativas e de convivência.

Foi criado e está em fase de implantação o Sistema de Acompanhamento da Condicionalidade do Trabalho Infantil (Sispeti), que é da rede SUAS-web ${ }^{20}$. Tratase de um sistema informatizado de acompanhamento das famílias que tenham crianças e adolescentes em situação de trabalho infantil, independentemente do programa do qual são beneficiárias. Quem alimenta o Sispeti são os municípios, que devem informar o cumprimento da condicionalidade da freqüência e as atividades oferecidas, e a Senarc, que alimenta quanto às crianças e aos adolescentes beneficiados.

Por sua vez, o problema do controle por intermédio dos recursos eletrônicos passa pela resolução de alguns problemas remanescentes no Cadastro, já que há um conjunto de municípios que não chegaram a cadastrar o número de famílias, crianças e adolescentes previsto em estimativas com base nos dados do IBGE. No total, o subcadastramento chega a pouco mais de $30 \%$ do valor total estimado, mas há municípios que estão com 60\% de defasagem. Isso pode resultar em vários fatores, entre os quais se destaca a falta de computadores com capacidade para sustentar os softwares do Cadastro; a falta de capacitação; e a rotatividade da mãode-obra que atua nessas atividades, o que anula os esforços de capacitação anteriormente realizados.

A Senarc desenvolve, junto aos municípios identificados, ações especificamente voltadas para corrigir essa distorção. $O$ problema dos equipamentos já vem sendo solucionado por meio de repasses de recursos para a sua atualização. Quanto ao pessoal, não apenas se oferece capacitação a distância, como a nova NOB-SUAS agora estabelece que haverá recursos federais para pagar esses profissionais nos municípios, de maneira a assegurar um quadro mais estável para as operações do cadastro.

Um último aspecto a ser explorado diz respeito ao problema essencial da sustentabilidade da política de erradicação do trabalho infantil: as oportunidades de trabalho e renda para as familias beneficiadas. Completamente ausente da concepção do $\mathrm{PBF}$, a preocupação em assegurar às famílias beneficiadas pelo PETI a possibilidade de sustento autônomo freqüentou brevemente o desenho desse último programa, sendo descontinuada a partir de 2004. 
A consulta aos gestores encarregados da integração dos dois programas, entretanto, suscitou a referência às ações de emprego e renda para os pais. Foi mencionada a ação dos CRAS e dos Centros de Referência Especializados de Assistência Social (Creas), para os quais as crianças e os adolescentes do PETI são uma prioridade, e que se localizam em áreas de vulnerabilidade e fazem o acompanhamento de um número determinado de famílias na sua base territorial, adotando medidas de inclusão produtiva, entre outras. Observa-se, entretanto, que tais medidas não têm o caráter de ações programáticas no âmbito específico do combate ao trabalho infantil, mas sim fazem parte das atividades de rotina dos CRAS e dos Creas.

\section{Principais constatações da avaliação da integração PETI-PBF}

foco desta avaliação incide fortemente sobre a implementação da integração do PETI ao PBF, ou seja, foram examinadas as estratégias, os insumos, os procedimentos e os arranjos, inclusive institucionais, adotados para produzir resultado. As dimensões examinadas foram: clareza e compartilhamento dos objetivos pelos gestores envolvidos no processo de integração; e adequação do desenho adotado para implementar a integração. É também uma avaliação de efetividade, compreendendo o exame dos efeitos dessa integração sobre a erradicação do trabalho infantil.

A integração destinava-se a transferir para o PBF as ações do PETI relativas à transferência de renda ${ }^{21}$, reduzindo esse programa às ações socioeducativas e de convivência e àquelas que, sob a condução do MTE, orientavam-se para a fiscalização do trabalho infantil.
A análise realizada mostra que os objetivos da integração foram claramente definidos e, mais que isso, acordados entre os atores. Conforme relatam os gestores:

"Anterior ao PBF havia uma orientação aos municípios no sentido de cadastrarem as crianças e os adolescentes do PETI. O que não havia era a obrigatoriedade (..). O processo de integração foi pactuado com todos os atores e em todas as instâncias, além de ter sido deliberado no CNAS, e isso foi fundamental para operacionalizar a execução. Em virtude de diversas dificuldades, os prazos foram repactuados cinco vezes, mas ainda assim, do total de 1,1 milhão de crianças e adolescentes previstos, foram cadastrados 860 mil. Então, pactuou-se com as Comissões Intergestoras Bipartites (CBI) que os municípios informassem ao MDS quais as dificuldades que enfrentam no cadastramento para que, uma vez identificados os municípios e os problemas, as famílias pudessem continuar recebendo mesmo fora do Cadastro. Isso foi até outubro de 2006. E, em novembro, o repasse fundo-a-fundo para esse fim foi suspenso".

O desenho adotado para implementar a integração, via inclusão das famílias no CadÚnico, também mostrou-se adequado, desde que se tenha claro que esse é um procedimento estritamente instrumental, ou seja: seria inteiramente viável a inclusão das famílias com crianças e adolescentes em situação de trabalho infantil no CadÚnico sem que isso implicasse, nem remotamente, a alteração do sistema de incentivos à retirada de crianças e adolescentes do trabalho precoce. A melhor 
evidência disso é que, após a integração, permanecem diversas famílias como beneficiárias da ação de transferência de renda do PETI, ainda que essa ação tenha assumido uma condição residual.

Portanto, teria sido possível, por intermédio do CadÚnico, gerenciar melhor a alocação dos benefícios, monitorar o cumprimento das condicionalidades, bem como a oferta e o comparecimento às atividades socioeducativas e de convivência - sem necessariamente substituir o critério do trabalho infantil pelo da renda, como veio a ocorrer.

A partir do estabelecimento das dimensões exploradas nessa avaliação, aplicaram-se os seguintes critérios:

Eficácia: cabem dúvidas sobre a contribuição da integração para o cumprimento dos objetivos e das metas de combate ao trabalho infantil no Brasil, devido aos problemas da perda dos incentivos por uma parte das famílias egressas do PETI, descritas na categoria 1; e à ausência de incentivos para as novas famílias.

A eficácia da integração, em termos do combate ao trabalho infantil, também pode ser comprometida por causa dos problemas com as ações socioeducativas e de convivência (inclusive o controle social) e das dificuldades de emprego e renda das famílias. Esses aspectos não foram resolvidos, como também não o foram os problemas de fiscalização do trabalho infantil. Aparentemente, a estratégia é substituir o controle social pelo controle virtual, mas isso também tem limitações, como mostra o subcadastramento pelos municípios.

Ou seja, a integração não resolveu os principais problemas do PETI e ainda colocou a área do controle com um desenho ainda mais precário.

Eficiência: aparentemente a integração contribuiu para a maximização dos resultados na aplicação dos recursos do PETI, já que, por meio do CadÚnico, foram identificados e poderão ser corrigidos problemas de duplicidade do cadastro, e por meio do Sispeti poderá ser acompanhado o cumprimento dos compromissos para com a oferta das ações socioeducativas e de convivência pelos municípios etc. Mas isso poderia ser feito sem a integração pelo critério de renda, sem a eliminação dos incentivos à retirada de crianças e adolescentes do trabalho infantil.

Não há dados conclusivos sobre a ampliação e garantia do acesso às atividades socioeducativas e de convivência para todas as crianças e adolescentes ex-trabalhadores atendidos pelo PETI e pelo PBF. Pelo menos no ano de 2006, a resposta aparentemente é negativa.

Apesar da unificação do per capita repassado ${ }^{22}$, que por si representa uma expansão do gasto, o valor executado foi menor do que o previsto para 2006 e do que o executado em 2005.

Ou seja: o valor executado em 2006 foi menor que o valor previsto para o atendimento de crianças e adolescentes do PETI; mais crianças e adolescentes em situação de trabalho infantil incorporadas por serem beneficiárias do PBF; mais todas as crianças abaixo de seis anos, com repasse per capita de $\mathrm{R} \$ 20,00$ por criança assistida, independentemente do tipo de município. Além disso, o valor executado em 2006 ficou abaixo do valor executado em 2005, relativo estritamente a crianças e adolescentes beneficiários do PETI, na faixa etária de sete a 15 anos, e ao valor per capita de $\mathrm{R} \$ 20,00$, para os municípios urbanos, e de $\mathrm{R} \$ 10,00$ para os municípios rurais.

Não há informação conclusiva sobre a definição dos parâmetros pedagógicos para as ações socioeducativas e de convivência de modo a contemplar o atendimento às 
crianças abaixo de seis anos, mas a resposta aparentemente é negativa, para essa e para as demais faixas etárias.

Efetividade: ainda não houve tempo suficiente para averiguar a efetividade das medidas da integração dos programas. Os dados da Pnad 2005 mostram um crescimento dos registros de trabalho infantil, mas esses não podem ser atribuídos à integração, que se iniciou em março de 2006.

Porém, ao equalizar o tratamento das famílias que possuem crianças e adolescentes em situação de trabalho infantil e as que não registram essa prática (categorias 6, 7, 8, 9, do Quadro 3), a integração elimina os incentivos das famílias à retirada de crianças e adolescentes da situação do trabalho infantil. Se tudo continuar como está, isso poderá levar ao recrudescimento da prática do trabalho precoce.

Eqüidade: a principal estratégia para a promoção da eqüidade foi a adoção da renda como critério do PBF e da integração PETI-PBF. Porém, ao adotar estritamente esse critério, perde-se de vista a especificidade do trabalho infantil, ou seja, houve perda do foco do trabalho infantil.

Transparência: indubitavelmente, o Cadastro Único traz ganhos de transparência e pode contribuir para o aprimoramento da gestão dos programas. Porém, a incorporação das famílias com crianças e adolescentes em trabalho infantil ao Cadastro não dependeria da alteração das ações de transferência de renda nos moldes estabelecidos pela Portaria 666, de 2005. Por outro lado, mesmo considerando a sua potencial contribuição para a transparência da ação pública, o Cadastro Único ainda merece muita atenção a fim de superar os problemas que enfrenta, desde o subcadastramento até a duplicidade.
Participação social: desde as primeiras auditorias do PETI e do PBF foram apontadas as fragilidades dos canais de participação social. Aparentemente, a integração, tal como estabelecida pela Portaria 666, de 2005, não contribuiu para a superação dessas dificuldades.

No que se refere ao trabalho infantil, embora a rede pública de fiscalização possivelmente venha a contribuir para o aprimoramento do processo de fiscalização, monitoramento e avaliação do PBF, dos programas remanescentes e do Cadastro Único, não ficam claros os ganhos que poderá trazer para o combate ao trabalho infantil.

Sustentabilidade: infelizmente, a análise da integração PETI-PBF sinaliza fortemente para a redução da sustentabilidade da política de combate ao trabalho infantil. A falta de definição precisa e pactuada do conceito de trabalho infantil e de ações socioeducativas de convivência; a ausência de parâmetros para essas ações com base nas práticas pedagógicas; a descaracterização das atividades de qualificação profissional e inclusão ocupacional das famílias beneficiárias e a perda dos incentivos à retirada das crianças e adolescentes da situação de trabalho apontam para a redução da sustentabilidade das ações governamentais na área.

\section{Recomendações e indicadores}

Além das recomendações relativas ao acompanhamento da elaboração do PPA, especialmente no ano em curso, e do orçamento (LDO e LOA), quanto à política de erradicação do trabalho infantil deve-se enfatizar a importância dos esforços para:

- introduzir o imperativo do registro e a fiscalização do trabalho infantil como 
condição de concessão de subsídios e financiamentos no âmbito da agricultura familiar;

- atribuir prioridade à definição dos parâmetros pedagógicos para as ações socioeducativas e de convivência, para todas as crianças e adolescentes beneficiários dos programas sociais do governo, destacandose os grupos de zero a seis anos, em sua especificidade;

- atribuir prioridade ao desenho e implementação de um sistema de monitoramento e avaliação das ações socioeducativas e de convivência, com base nas informações do Sispeti.

- apoiar fortemente as ações do MTE na fiscalização do trabalho infantil, inclusive mediante o fortalecimento da parceria com o Ministério Público;
- propor aperfeiçoamentos nos instrumentos de coleta de dados do CadÚnico, de modo a registrar com mais cuidado as informações sobre o trabalho infantil;

- propor procedimentos de mais transparência do CadÚnico, de sorte que todos os atores interessados possam acompanhar os resultados da integração sobre a erradicação do trabalho infantil;

- propor que o diálogo sobre as ações de combate e erradicação do trabalho infantil e seus resultados tenha por base o uso de indicadores a serem alimentados pelos atores envolvidos no arranjo institucional da assistência social. No quadro ao lado, são apresentados alguns dos indicadores para essa finalidade.

(Artigo recebido em outubro de 2007. Versão final em dezembro de 2007.) 


\begin{tabular}{|c|c|}
\hline Indicadores de resultados & Indicadores de processo \\
\hline $\begin{array}{l}\text { Número de crianças/adolescentes exercendo } \\
\text { atividade laboral no ano X. Número de } \\
\text { crianças/adolescentes exercendo atividade } \\
\text { laboral no ano X-1 por município e por } \\
\text { estado. }\end{array}$ & $\begin{array}{l}\text { Número de crianças/adolescentes atendidos } \\
\text { pelo PETI*/Número de crianças/ } \\
\text { adolescentes ocupados em atividades } \\
\text { laborais. }\end{array}$ \\
\hline $\begin{array}{l}\text { Número de crianças/adolescentes economi- } \\
\text { camente ativos de } 5 \text { a } 15 \text { anos por unidade } \\
\text { territorial/Número de crianças/adolescentes } \\
\text { de } 5 \text { a } 15 \text { anos, por unidade territorial. }\end{array}$ & $\begin{array}{l}\text { Número de unidades territoriais atendidas } \\
\text { pelo PETI*/Número de unidades } \\
\text { territoriais com ocorrência de trabalho } \\
\text { infantil. }\end{array}$ \\
\hline $\begin{array}{l}\text { Variação anual da renda per capita das famílias } \\
\text { atendidas pelo PETI* menos o acréscimo } \\
\text { proveniente de beneficio de programa social/ } \\
\text { Variação anual da renda per capita das famílias } \\
\text { de crianças/adolescentes trabalhadores não } \\
\text { atendidos pelo PETI*. }\end{array}$ & $\begin{array}{l}\text { Número anual de horas destinadas para ati- } \\
\text { vidades socioeducativas para conscientização } \\
\text { dos adultos. }\end{array}$ \\
\hline $\begin{array}{l}\text { Variação anual do número de crianças/ado- } \\
\text { lescentes encontrados trabalhando durante } \\
\text { ação fiscalizatória e o número de crianças/ } \\
\text { adolescentes beneficiários de ações socio- } \\
\text { educativas e de convivência, por município e } \\
\text { por estado. }\end{array}$ & $\begin{array}{l}\text { Número de reuniões com quórum das } \\
\text { Comissões Municipais de Erradicação do } \\
\text { Trabalho Infantil. }\end{array}$ \\
\hline $\begin{array}{l}\text { Razão entre a taxa de freqüência escolar das } \\
\text { crianças/adolescentes beneficiários do PETI* } \\
\text { e a taxa de freqüência escolar das crianças/ado- } \\
\text { lescentes dos demais programas sociais. }\end{array}$ & $\begin{array}{l}\text { Número mensal de crianças/adolescentes de } \\
\text { até } 15 \text { anos participantes de atividades socio- } \\
\text { educativas e de convivência oferecidas pelo } \\
\text { PETI*. }\end{array}$ \\
\hline $\begin{array}{l}\text { Razão entre a taxa de abandono escolar das } \\
\text { crianças/adolescentes atendidos pelo PETI* } \\
\text { e a taxa de abandono escolar das crianças/ } \\
\text { adolescentes dos demais programas sociais. }\end{array}$ & $\begin{array}{l}\text { Número de horas/homem/ano de ativi- } \\
\text { dades socioeducativas e de convivência } \\
\text { oferecidas às famílias do PETI*. }\end{array}$ \\
\hline $\begin{array}{l}\text { Razão entre o número de matrículas na } 5^{\underline{a}} \\
\text { série das crianças/adolescentes do PETI* } \\
\text { com mais de } 10 \text { anos e o número de matrí- } \\
\text { culas na } 5^{\underline{a}} \text { série para as crianças/adolescen- } \\
\text { tes dos demais programas sociais com mais } \\
\text { de } 10 \text { anos. }\end{array}$ & $\begin{array}{l}\text { Número médio mensal de crianças/adoles- } \\
\text { centes por monitor das atividades socio- } \\
\text { educativas e de convivência oferecidas pelo } \\
\text { PETI*. }\end{array}$ \\
\hline $\begin{array}{l}\text { Razão entre a taxa de defasagem idade/série } \\
\text { das crianças/adolescentes do PETI* e a taxa } \\
\text { de defasagem idade/série das crianças/adoles- } \\
\text { centes dos demais programas sociais. }\end{array}$ & $\begin{array}{l}\text { Número de horas destinadas à capacitação dos } \\
\text { monitores das atividades socioeducativas e } \\
\text { de convivência oferecidas pelo PETI* } \\
\text { Número anual de famílias que participaram } \\
\text { de atividades de conscientização sobre os } \\
\text { malefícios do trabalho infantil no âmbito do } \\
\text { PETI*. }\end{array}$ \\
\hline
\end{tabular}

(*) Refere-se, sempre, à oferta de ações socioeducativas e de convivência, nunca ao benefício financeiro. 


\section{Notas}

${ }^{1}$ Principal instrumento de gestão do PBF, o Cadastro Único de programas sociais do governo federal foi instituído pelo Decreto $\mathrm{n}^{\circ} 3.877$, de 24 de julho de 2001, e consolidado mediante a Portaria 360 , de 12 de julho de 2005, que define os critérios e procedimentos relativos à transferência de recursos financeiros a municípios, estados e ao Distrito Federal, destinados à implementação e desenvolvimento do PBF e à manutenção e aprimoramento do Cadastro Único de programas sociais.

${ }^{2}$ Resolução nº 196, de 1996, do Conselho Nacional de Saúde, que estabelece as diretrizes e normas regulamentadoras sobre pesquisa envolvendo seres humanos, item III. 3 - "A pesquisa em qualquer área do conhecimento, envolvendo seres humanos deverá observar as seguintes exigências:...(1) prever procedimentos que assegurem a confidencialidade e a privacidade, a proteção da imagem e a não estigmatização, garantindo a não utilização das informações em prejuízo das pessoas e/ou das comunidades, inclusive em termos de auto-estima, de prestígio e/ou econômico-financeiro (...)".

${ }^{3}$ Segundo a Portaria 2.917, de 12 de setembro 2000, e a Portaria 458, de 4 de outubro de 2001: "prioritariamente, às famílias com renda per capita de até $1 \frac{1}{2}$ salário mínimo".

${ }^{4} \mathrm{E}$, secundariamente: estudos e pesquisas sobre trabalho infantil; promoção de eventos para sensibilização da sociedade sobre o trabalho infantil; campanha para sensibilização da sociedade quanto ao trabalho infantil; edição e distribuição de publicações institucionais sobre trabalho infantil.

${ }^{5}$ Portaria $n^{\circ}$ 458, de 4 de outubro de 2001.

${ }^{6}$ Nos seus primeiros anos, o PETI operava com base nos Cadastros das Famílias baseados em modelo instituído pela SEAS, validados pelo órgão gestor estadual de assistência social em conjunto com a Comissão Estadual de Erradicação do Trabalho Infantil, encaminhados pelo órgão gestor estadual de Assistência Social à Secretaria de Estado de Assistência Social (Seas), para inserção no Sistema Nacional de Informações Gerenciais do PETI. Cabia à Secretaria Municipal de Assistência Social viabilizar o Cadastro de Informações Municipais para alimentar o Sistema Nacional de Informações Gerenciais do PETI. A partir da Portaria 458/2001, ficou estabelecido que os cadastros das famílias deveriam ser realizados em conformidade com o Decreto ${ }^{\circ} 3.877$ de 24 de julho de 2001, que instituiu o cadastramento único para programas sociais. Sobre o Cadastro Único, ver auditoria operacional do TCU, de 2003.

${ }^{7}$ O Programa Bolsa Família foi instituído pela Medida Provisória n 132, de 20 de outubro de 2003, convertida na Lei no ${ }^{2}$ 10.836, de 9 de janeiro de 2004. Essa lei refere-se à legislação dos programas que foram unificados, como a Lei no 10.219, de 11/4/01, que instituiu o Programa Bolsa-Escola, regulamentado pelo Decreto no 4.313, de 24 de julho de 2002; a Lei no 10.689, de 13 de junho de 2003, que criou o Programa Nacional de Acesso à Alimentação; a Medida Provisória no 2.206-1, de 6 de setembro de 2001, que instituiu o Programa Bolsa-Alimentação, regulamentado pelo Decreto no 3.934, de 20/9/01; o Decreto $n^{\circ} 4.102$, de 24 de janeiro de 2002, que instituiu o Programa Auxilio-Gás, e o Decreto nㅜ․877, de 24 de julho de 2001, que instituiu o Cadastramento Único do governo federal.

${ }^{8}$ A rede pública de fiscalização consiste na parceria no desenvolvimento e aprimoramento do processo de fiscalização, monitoramento e avaliação do Programa Bolsa Família, programas remanescentes e Cadastro Único. Mediante convênios com o objetivo de cooperação técnica para proteção dos bens, valores e direitos relativos ao Programa Bolsa Família e remanescentes e ao Cadastro Único, firmados com Conselho Nacional de Procuradores Gerais dos Ministérios Públicos dos estados e da União; Controladoria Geral da União; Ministérios Públicos Estaduais (26 Estados e o Distrito Federal); Ministério Público Federal; Ministério Público Militar; Tribunal de Contas da União.

Os instrumentos normativos que regem esse aspecto do PBF são: Portaria GM/MDS n 551, de 09 de novembro de 2005 - regulamenta a gestão das Condicionalidades do Programa Bolsa Família; Portaria Interministerial MS/MDS n² 2.509 de 18 de novembro de 2004 - estabelece atribuições e 
normas para o acompanhamento das Condicionalidades de Saúde no Programa Bolsa Família; Portaria Interministerial MEC/MDS no 3.789 de 17 de novembro de 2004 - estabelece atribuições e normas para o acompanhamento das Condicionalidades de Educação no Programa Bolsa Família.

${ }^{10} \mathrm{O}$ conjunto completo das atividades de gestão dos benefícios do PBF compreende: bloqueio de benefícios; desbloqueio de benefícios; suspensão de beneficios; reversão de suspensão de benefícios; cancelamento de benefício básico; reversão de cancelamento de benefício básico; cancelamento de benefícios variáveis; reversão de cancelamento de benefícios variáveis; cancelamento de benefícios; $\mathrm{e}$ reversão de cancelamento de benefícios. Para a execução das atividades de gestão de benefícios a Senarc utiliza o Sistema de Gestão de Benefícios do PBF.

${ }^{11}$ Capítulo II - Da Seleção de Famílias e da Concessão e Manutenção de Benefícios Financeiros do PBF e do PETI

Art. $4^{\circ}$ No que se refere ao componente de transferência de renda, as famílias em situação de trabalho infantil, ainda não inscritas no PETI ou no PBF, deverão ser incluídas:

I) no PBF, caso tenham renda per capita mensal igual ou inferior a $\mathrm{R} \$ 100,00$ (cem reais); ou

II) no PETI, caso tenham renda per capita mensal superior a $R \$ 100,00$ (cem reais).

Art. 5 A seleção de famílias para ingresso no PBF seguirá as regras definidas na Lei no 10.836 , de 2004, sendo consideradas, para efeito de concessão de benefícios financeiros mencionados no Art. $3^{\circ}$, I, desta Portaria, as famílias em situação de trabalho infantil que apresentem:

I) renda familiar per capita mensal igual ou inferior a $R \$ 100,00$ (cem reais);

II) informações da família corretamente inseridas no Cadastramento Único de Programas Sociais do Governo Federal - CadÚnico, instituído pelo Decreto n 3.877, de 24 de julho de 2001; e

III) situação de trabalho infantil de que trata o caput, devidamente registrada no CadÚnico, segundo as regras definidas nesta Portaria.

Parágrafo Único. A concessão dos benefícios financeiros do PBF será efetuada pela Secretaria Nacional de Renda de Cidadania (SENARC), respeitada a disponibilidade orçamentário-financeira existente.

Art. $6^{\circ}$ A seleção de famílias para ingresso no PETI seguirá as regras definidas na Portaria SEAS/ MPAS $n^{\circ} 458$, de 2001, sendo consideradas para efeito de concessão de benefícios financeiros de que trata o Art. 3ㅜ, III, as famílias:

I) Cuja renda familiar per capita mensal seja superior a $\mathrm{R} \$ 100,00$ (cem reais);

II) Cujas informações estejam corretamente inseridas no CadÚnico; e

III) cuja situação de trabalho infantil seja devidamente registrada no CadÚnico, segundo as regras definidas nesta Portaria.

Parágrafo único. A concessão dos benefícios financeiros de que trata o caput para as famílias selecionadas será efetuada pela Secretaria Nacional de Assistência Social (SNAS), respeitada a disponibilidade orçamentário-financeira existente, segundo o disposto no Art. 15 desta Portaria.

Art. $7^{\circ}$. Serão gradualmente transferidas para o PBF, respeitada a disponibilidade orçamentária e financeira existente, as famílias usuárias do PETI que apresentarem, simultaneamente, as seguintes características:

I) Renda familiar per capita mensal igual ou inferior a $\mathrm{R} \$ 100,00$ (cem reais); $\mathrm{e}$

II) Benefícios financeiros do PETI operacionalizados pela Caixa Econômica Federal.

$\int 1^{\circ}$ Permanecerão no PETI operacionalizado pela Caixa Econômica Federal, para todos os efeitos, as famílias:

Que possuam apenas os benefícios financeiros do PETI; e cuja transferência para o PBF implique redução no montante dos benefícios financeiros recebidos do PETI operacionalizados pela Caixa Econômica Federal.

$\int 2^{\circ}$ As famílias que recebem benefícios financeiros do PETI, operacionalizados mediante convênios firmados pelos entes federados com o Fundo Nacional de Assistência Social (FNAS), serão gradualmente incluídas no PBF ou no PETI operacionalizado pela Caixa Econômica Federal, desde que estejam inscritas no CadÚnico, respeitado ainda o seguinte: 
I) Se a renda per capita mensal da família for superior a $R \$ 100,00$ (cem reais), a família será incluída no PETI operacionalizado pela Caixa Econômica Federal, mantendo os benefícios financeiros dos programas remanescentes, caso existentes;

II) Se a família possui renda per capita mensal igual ou inferior a $\mathrm{R} \$ 100,00$ (cem reais), a família será incluída no PBF, sem prejuízo do disposto no Art. $8^{\circ}$ desta Portaria.

Art. $8^{\circ}$ As famílias que sejam simultaneamente usuárias do PETI e beneficiárias dos Programas Bolsa Alimentação, Cartão Alimentação ou Auxílio Gás, e forem transferidas para o PBF, farão jus ao Benefício Variável de Caráter Extraordinário".

${ }^{12}$ Em síntese: as regras gerais da integração estabelecem que a família com "renda per capita menor que $\mathrm{R} \$ 120,00$, receberá transferência de renda pelo $\mathrm{PBF}$, salvo se tiver prejuízo; se a renda per capita for maior que $\mathrm{R} \$ 120,00$, receberá transferência de renda pelo PETI”. Entretanto, há vários outros aspectos específicos que merecem análise, apresentados no Quadro 3.

${ }^{13} \mathrm{O}$ artigo $7^{\circ}$ da Portaria 666, de 2005 , não menciona essa possibilidade; ela foi deduzida das regras gerais do $\mathrm{PBF}$.

${ }^{14}$ Idem.

${ }^{15}$ Aspas da autora.

${ }^{16}$ As instruções detalhadas para o preenchimento encontram-se na instrução operacional conjunta Senarc/SNAS MDS nº 01, de 14 de março de 2006, que divulga aos municípios orientações sobre a operacionalização da integração entre o Programa Bolsa Família e o Programa de Erradicação do Trabalho Infantil, no que se refere à inserção, no Cadastro Único, das famílias beneficiárias do PETI e famílias com crianças/adolescentes em situação de trabalho.

${ }^{17}$ Esse é um dos motivos pelos quais na ação de fiscalização do trabalho infantil, sob a responsabilidade do MTE, realizou-se trabalho de mapeamento dos focos de trabalho infantil no Brasil, mas, de acordo com auditoria do TCU, não havia identificação ou quantificação das crianças/adolescentes em situação de trabalho infantil, mas somente da distribuição geográfica dos focos.

${ }^{18}$ O MTE desenvolveu estratégias para identificar o trabalho infantil: são ações denominadas "operativos", que não são apenas repressivas (fiscalização), mas envolvem sensibilização e conscientização como elemento de sustentabilidade. Cada DRT é obrigada a fazer no mínimo quatro operativos/ano, sendo dois nacionais, em datas planejadas e previamente estabelecidas com o Ministério. Porém, geralmente, as DRTs fazem de quatro a seis operativos/ano. O foco do operativo é territorial: locais, regiões, atividades em que houver maior índice de TI segundo a Pnad e o Mapa de informações dos parceiros locais - alguns exemplos são o Fortal de Fortaleza, em julho; as crianças/adolescentes catando latinha no carnaval em Salvador; as safras agrícolas; as festas de peão boiadeiro; as festas do morango, da maçã etc.

${ }^{19}$ Ver Guedes, Márcia. A Integração entre o Programa Bolsa Família e o Programa de Erradicação do Trabalho Infantil, Brasília: Fórum Nacional par Erradicação do Trabalho Infantil, março de 2006. Mimeo. p. 23.

${ }^{20}$ Ferramenta criada pelo MDS para agilizar a transferência regular e automática de recursos financeiros do Fundo Nacional de Assistência Social (FNAS) para os fundos estaduais, do Distrito Federal e municipais.

${ }^{21}$ Embora a Lei no 10.836/2004 só mencione a unificação do Programa Nacional de Renda Mínima vinculado à Educação (Bolsa Escola, instituído pela Lei nº 10.219/2001), do Programa Nacional de Acesso à Alimentação (PNAA, criado pela Lei no 10.689/2003), do Programa Nacional de Renda Mínima vinculado à Saúde (Bolsa Alimentação, instituído pela Medida Provisória n⿳⺈ 2.206-1/2001), do Programa Auxílio-Gás (instituído pelo Decreto nº 4.102/2002), e do Cadastramento Único do Governo Federal (instituído pelo Decreto nº 3.877/2001), não se referindo ao Programa de Erradicação do Trabalho Infantil.

${ }^{22}$ De acordo com os gestores, deixou de haver diferença nos valores repassados a municípios rurais e urbanos, passando todos a receber $R \$ 20,00$ por criança/adolescente assistido com tais ações. 


\section{Documentos consultados}

Decreto $\mathrm{n}^{\circ}$ 3.877, de 24 de julho de 2001. Cadastramento Único para Programas Sociais do Governo Federal.

Decreto no 5.209, de 17 de setembro de 2004. Regulamentação da Lei nº 10.836, de 09/01/2004, que cria o Programa Bolsa Família, e dá outras providências.

DeCRETo no 5.749, de 11 de abril de 2006. Atualização dos valores referenciais para caracterização das situações de pobreza e extrema pobreza, no âmbito do Programa Bolsa Família.

Instrução Operacional Conjunta Senarc/Mds no 01, de 14 de março de 2006. Divulgação, aos municípios, das orientações sobre a operacionalização da integração entre o Programa Bolsa Família e o Programa de Erradicação do Trabalho Infantil, no que se refere à inserção, no Cadastro Único, das famílias beneficiárias do PETI e famílias com crianças/adolescentes/adolescentes em situação de trabalho.

Instrução Operacional Conjunta Senarc/Mds no 01, de 14 de março de 2006. Divulgação, aos municípios, das orientações sobre operacionalização da integração entre o Programa Bolsa Família e o Programa de Erradicação do Trabalho Infantil, no que se refere à inserção, no Cadastro Único, das famílias beneficiárias do PETI e famílias com crianças/adolescentes/adolescentes em situação de trabalho.

Instrução Operacional Senarc/Mds no 1, de 19 de maio de 2004. Divulgação dos procedimentos operacionais aos municípios para tratamento de bloqueios por multiplicidade cadastral.

Instrução Operacional Senarc/Mds no 10, de 31 de agosto de 2005. Divulgação das orientações e procedimentos operacionais aos municípios e esclarecimentos sobre procedimentos utilizados pelo Governo Federal para marcação de domicílios ativos e inativos no Cadastro Único.

Instrução Operacional Senarc/Mds no 11, de 22 de novembro de 2005. Divulgação da auditoria realizada sobre o Cadastro Único de Programas Sociais do Governo Federal e sua repercussão sobre os benefícios dos programas de transferência de renda do Governo Federal.

Instrução Operacional Senarc/Mds no 12, de 3 de fevereiro de 2006. Divulgação, aos municípios, das orientações sobre a repercussão automática de alterações cadastrais do Cadastro Único de Programas Sociais do Governo Federal no Sistema de Gestão de Benefícios do Programa Bolsa Família.

Instrução Operacional Senarc/Mds no 13, de 20 de abril de 2006. Divulgação dos critérios utilizados para o processamento do bloqueio dos benefícios dos Programas Remanescentes com base no CADBES e orientação às Prefeituras acerca da complementação dos dados e do desbloqueio dos benefícios.

Instrução Operacional Senarc/Mds no 14, de 10 de agosto de 2006. Divulgação da auditoria realizada sobre o Cadastro Único de Programas Sociais do Governo Federal e sua repercussão sobre os benefícios do Programa Bolsa Família. 
Guedes, Márcia. A integração entre o Programa Bolsa-Familia e o Programa de Erradicação do Trabalho Infantil. Brasília: Fórum Nacional para Erradicação do Trabalho Infantil, 2006.

Instrução Operacional Senarc/Mds no 15, de 13 de dezembro de 2006. Divulgação, aos estados e aos municípios, das orientações sobre os procedimentos para Credenciamento de Usuários ao Sistema de Gestão de Benefícios do Programa Bolsa Família.

Instrução Operacional Senarc/Mds no 4, de 14 de fevereiro de 2005. Divulgação dos procedimentos operacionais aos municípios para tratamento de bloqueios por multiplicidade cadastral.

Instrução Operacional Senarc/Mds no 5, de 15 de fevereiro de 2005. Divulgação dos procedimentos operacionais aos municípios para importação de base cadastral do Cadastro Único.

Instrução Operacional Senarc/Mds no 7, de 20 de maio de 2005. Divulgação, aos municípios, das instruções sobre procedimentos operacionais para o tratamento de eventuais inconsistências nos dados do Cadastro Único; publicação dos novos critérios de validação dos registros desse cadastro; e definição de orientações para análise e validação dos resultados da comparação dos dados de renda do Cadastro Único com os da Relação Anual de Informações Sociais de 2003.

Instrução Operacional Senarc/Mds no 8, de 20 de junho de 2005. Divulgação da auditoria realizada sobre as folhas de pagamento dos programas de transferência de renda do Governo Federal, assim como orientação aos municípios para tratamento de casos de multiplicidade cadastral.

Instrução Operacional Senarc/Mds no 9, de 05 de agosto de 2005. Divulgação das instruções sobre os procedimentos operacionais necessários à formalização da adesão dos municípios ao Programa Bolsa Família e ao Cadastro Único de Programas Sociais; orientação aos gestores e aos técnicos sobre a designação do gestor municipal do BolsaFamília e a formalização da Instância de Controle Social do Programa, e especificação da documentação a ser anexada para fins de comprovação das medidas adotadas.

LEI no 10.836, de 09 de janeiro de 2004. Criação do Programa Bolsa Família e outras providências.

LEI no 11.326, de 24 de julho de 2006. Estabelece as diretrizes para a formulação da Política Nacional da Agricultura Familiar e Empreendimentos Familiares Rurais.

MDS. Cartilha do PETI/2004.

MDS. Agenda de compromissos da familia.

- Guia do gestor do Programa Bolsa Familia.

- Manual de orientações sobre o Bolsa Familia na Saúde.

- Manual operacional da frequiencia escolar.

Orientaç̃es para o acompanhamento das familias beneficiárias do Programa Bolsa

Familia no âmbito do Sistema Único de Assistência Social (SUAS). Versão preliminar.

MDs/Snas. Orientações para o acompanhamento das familias beneficiárias do Programa Bolsa Familia no Âmbito do Sistema Único de Assistência Social (SUAS), 2006.

Mds/Snas/Unicef. Análise situacional do Programa de Erradicação do Trabalho Infantil PETI, 2004. 
Medida Provisória no 132, de 20 de outubro de 2003. Criação do Programa Bolsa Família e outras providências (convertida na Lei no 10.836 , de 09/01/2004).

Mds/Snas. Portaria no 2.917 , de 12 de Setembro 2000. Diretrizes e Normas do Programa de Erradicação do Trabalho Infantil - PETI.

PORTARIA GM/MDs no 148, de 27 de abril de 2006. Estabelecimentos de normas, critérios e procedimentos para o apoio à gestão do Programa Bolsa Família e do Cadastro Único de Programas Sociais do Governo Federal no âmbito dos municípios, e criação do Índice de Gestão Descentralizada do Programa.

Portaria Gm/Mds no 246, de 20 de maio de 2005. Instrumentos necessários à formalização da adesão dos municípios ao Programa Bolsa Família, à designação dos gestores municipais do Programa e à informação sobre sua instância local de controle social. Procedimento de adesão dos entes locais ao referido Programa.

Portaria Gm/MDs no 360 , de 12 de julho de 2005. Critérios e procedimentos relativos à transferência de recursos financeiros aos municípios, Estados e Distrito Federal, destinados à implementação e desenvolvimento do Programa Bolsa Família e à manutenção e aprimoramento do Cadastro Único de Programas Sociais.

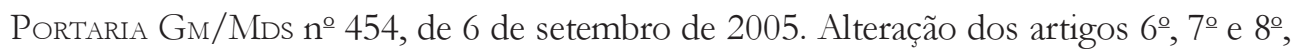
modificação do Anexo I e criação dos Anexos II e III da Portaria GM/MDS no 360, de 12 de julho de 2005.

PORTARIa Gm/Mdn no 532, de 3 de novembro de 2005. Regras de fixação do calendário de pagamento dos benefícios financeiros do Programa Bolsa Família e dos Programas Remanescentes.

PORTARIa Gm/MDs no 551, de 9 de novembro de 2005. Regulamentação da gestão das condicionalidades do Programa Bolsa Família.

Portaria GM/Mds no 555, de 11 de novembro de 2005. Normas e procedimentos para a gestão de benefícios do Programa Bolsa Família, criado pela Lei 10.836, de 9 de janeiro de 2004.

Portaria Gm/MDs no 660, de 11 de novembro de 2004. Autorização, em caráter provisório, dos Comitês Gestores do Cartão Alimentação e dos Conselhos Municipais de Assistência Social a realizar o controle social do Programa Bolsa Família.

Portaria Gm/Mds no 666, de 28 de dezembro de 2005. Integração entre o Programa Bolsa Família e o Programa de Erradicação do Trabalho Infantil.

Portaria Gm/Mds no 672, de 29 de dezembro de 2005. Alteração dos prazos fixados nas Portarias Gm/MDs no 246, de 20 de maio de 2005, GM/MDS no 360, de 12 de julho de 2005 e GM/MDs no 555, de 11 de novembro de 2005, e estabelecimento de critérios para remuneração no Cadastro Único das famílias beneficiárias do Programa de Erradicação do Trabalho Infantil (PETI).

Portaria Gm/Mds nº 68, de 08 de março de 2006. Alteração de prazos fixados nas Portarias Gm/MDs nº 246, de 20 de maio de 2005, GM/MDS nº 360, de 12 de julho de 2005 e GM/MDs no 555, de 11 de novembro de 2005.

Portaria Gm/Mds no 737, de 15 de dezembro de 2004. Regulamentação do Benefício Variável de Caráter Extraordinário do Programa Bolsa-Família. 
Portaria Gm/Ms no 2.246, de 18 de outubro de 2004. Orientações básicas para Ações de Vigilância Alimentar e Nutricional, no âmbito das ações básicas de saúde do Sistema Único de Saúde (SUS), em todo território nacional.

Portaria Interministerial Mec/Mds no 3.789, de 17/11/2004. Disposição sobre as atribuições e normas para a oferta e o monitoramento das ações de educação relativas às condicionalidades das famílias beneficiárias do Programa Bolsa Família.

Portaria Interministerial Ms/Mds nº 2.509, de 18/11/2004. Disposição sobre as atribuições e normas para a oferta e o monitoramento das ações de saúde relativas às condicionalidades das famílias beneficiárias do Programa Bolsa Família.

PorTaria no ${ }^{\circ}$ 256, de 18 de Julho de 2006. Alteração dos dispositivos da Portaria no 148 , de 27 de abril de 2006.

Portaria Senarc/Mds no 1 , de 3 de setembro de 2004. Ações voltadas ao desenvolvimento, aplicação e aprimoramento da metodologia-padrão construída para instrumentalizar, as atividades de fiscalização, acompanhamento e controle da execução e gestão local de programas municipais e estaduais, apoiados financeiramente pela União, do Programa Bolsa Família.

Presidência da República. Mensagem Presidencial 2007, p. 98-104.

Tribunal de Contas da União; Secretaria de Avaliação de Programas. Avaliação do Cadastro Único de Programas Sociais do Governo Federal, 2001.

- Relatório de Monitoramento da Implementação das Recomendações ao Programa de Erradicação do Trabalho Infantil, 2002. - Avaliação do Programa Bolsa Família, 2004. - Relatório de Monitoramento da Implementação das Recomendações ao Programa de Erradicação do Trabalho Infantil, 2005. 


\section{Resumo - Resumen - Abstract}

\section{Avaliação da integração do Programa de Erradicação do Trabalho Infantil ao Programa Bolsa Família}

Maria das Graças Rua

O artigo descreve e avalia o novo modelo do Programa de Erradicação do Trabalho Infantil (PETI) integrado ao Programa Bolsa Família (PBF). Mostra que o desenho para implementar a integração contribuiu para racionalização e aprimoramento dos processos de gestão do PBF e PETI: pelo Cadastro Único, reduziu gastos administrativos, facilitou monitoramento e avaliação e contribuiu para melhor aplicação dos recursos do PETI; pelo SISPETI, tornou possível acompanhar a oferta das ações socioeducativas e de convivência pelos municípios. Argumenta que, como as causas do trabalho infantil vão além da insuficiência de renda, ao enfatizar o critério da renda e equalizar o tratamento das famílias que possuem crianças e adolescentes em situação de trabalho infantil e as que não registram essa prática, o modelo de integração adotado pode ter tornado frágeis os incentivos à retirada das crianças e adolescentes do trabalho infantil. Conseqüentemente, pode ter enfraquecido a política de combate ao trabalho infantil.

Palavras-chave: trabalho infantil; Programa de Erradicação do Trabalho Infantil; Programa Bolsa Família.

\section{Evaluación de la integración del Programa de Erradicación del Trabajo Infantil al Programa Bolsa Família}

Maria das Graças Rua

El artículo describe y evalúa el nuevo modelo del Programa de Erradicación del Trabajo Infantil (PETI) integrado al Programa Bolsa Familia. Muestra que el diseño para implementar la integración contribuye para la racionalización y perfeccionamiento de los procesos de gestión del PBF y del PETI: por medio del Cadastro Único, se redujo los gastos administrativos, se facilitó el monitoramiento y la evaluación y se contribuyó para la mejora de aplicación de los recursos del PETI; y a través del SISPETI, fue posible a los municipios acompañar la oferta de las acciones socioeducativas y de convivencia. También argumenta que, como las causas del trabajo infantil van más allá de la insuficiencia de renta, al enfatizar el criterio de la renta e al igualar el tratamiento de las familias que poseen niños / jóvenes en situación de trabajo infantil y de las que no registran esta práctica, el modelo de integración adoptado debilitó los incentivos para la retirada de los niños/jóvenes del trabajo infantil y, en consecuencia, puso frágil a la política del Estado de combate a esta forma de trabajo

Palabras clave: trabajo infantil; Programa de Erradicación del Trabajo Infantil; Programa Bolsa Família.

\section{Evaluation of the integration of the Child Labor Eradication Program with the Bolsa Família Program}

Maria das Graças Rua

The article describes and evaluates the new model of the Child Labor Eradication Program (PETI), integrated to the Bolsa Familia Program (PBF). It shows that the design to implement their integration has contributed to the rationalization and improvement of the management processes in both programs: through the Unified Enlistment, it has reduced administrative costs, facilitated the monitoring and evaluation and has contributed to a better resources management for PETI; through the SISPETI it was made possible to provide the offer of socio-educational and other 
judicial measures for youngsters in the municipalities. It argues that, as the causes of child labor actually go beyond poor income, by emphasizing the income criteria and equalizing the treatment of families with children and adolescents in child labor situation and the families whose children do not work, the integration model made fragile the incentives to withdraw youngsters in child labor situation. Consequently, it may have weakened the child labor eradication policy.

Key-word: child labor; Child Labor Eradication Program; Bolsa Família Program.

Maria das Graças Rua

É mestre e doutora em Ciência Política (IUPERJ), graduada em Ciências Sociais, Professora Adjunto IV da Universidade de Brasília. Consultora de organismos internacionais na área de monitoramento e avaliação de políticas públicas. Contato: mgracasrua@uol.com.br 